\title{
Molecular Insights in Atrial Fibrillation Pathogenesis and Therapeutics: A Narrative Review
}

\author{
Konstantinos A. Papathanasiou ${ }^{1,+} \oplus$, Sotiria G. Giotaki ${ }^{1,+}{ }^{,}$Dimitrios A. Vrachatis ${ }^{1}{ }^{\circledR}$, Gerasimos Siasos ${ }^{1}$, \\ Vaia Lambadiari ${ }^{1}$, Konstantinos E. Iliodromitis ${ }^{2}$, Charalampos Kossyvakis ${ }^{3}{ }^{\circledR}$, Andreas Kaoukis ${ }^{3}$, \\ Konstantinos Raisakis ${ }^{3}$, Gerasimos Deftereos ${ }^{3}$, Theodore G. Papaioannou ${ }^{1}$, Georgios Giannopoulos ${ }^{4}$, \\ Dimitrios Avramides ${ }^{3}$ and Spyridon G. Deftereos ${ }^{1, *}$
}

1 Medical School, National and Kapodistrian University of Athens, 11527 Athens, Greece; kpapathanasiou91@gmail.com (K.A.P.); sotiria.giotaki@yahoo.com (S.G.G.); dvrachatis@gmail.com (D.A.V.); ger_sias@hotmail.com (G.S.); vlambad@otenet.gr (V.L.); teogpap@gmail.com (T.G.P.)

2 Evangelisches Krankenhaus Hagen-Haspe, Clinic for Cardiology and Electrophysiology, 58135 Hagen, Germany; konstantinos.iliodromitis@gmail.com

3 Department of Cardiology, "G. Gennimatas" General Hospital of Athens, 11527 Athens, Greece; ckossyvakis@gmail.com (C.K.); andreaskaoukis@yahoo.gr (A.K.); kraisakis@yahoo.co.uk (K.R.); gerasimosd@gmail.com (G.D.); d_avramides@yahoo.com (D.A.)

4 Medical School, Aristotle University of Thessaloniki, 54124 Thessaloniki, Greece; ggiann@med.uoa.gr

* Correspondence: spdeftereos@gmail.com; Tel.: +30-21-0583-2355

+ Equal contribution.

check for updates

Citation: Papathanasiou, K.A.; Giotaki, S.G.; Vrachatis, D.A.; Siasos, G.; Lambadiari, V.; Iliodromitis, K.E.; Kossyvakis, C.; Kaoukis, A.; Raisakis, K.; Deftereos, G.; et al. Molecular Insights in Atrial Fibrillation Pathogenesis and Therapeutics: A Narrative Review. Diagnostics 2021, 11, 1584. https://doi.org/10.3390/ diagnostics11091584

Academic Editor: Vasileios Vassilikos

Received: 12 August 2021

Accepted: 30 August 2021

Published: 31 August 2021

Publisher's Note: MDPI stays neutral with regard to jurisdictional claims in published maps and institutional affiliations.

Copyright: (c) 2021 by the authors. Licensee MDPI, Basel, Switzerland This article is an open access article distributed under the terms and conditions of the Creative Commons Attribution (CC BY) license (https:/ / creativecommons.org/licenses/by/ $4.0 /)$.

\begin{abstract}
The prevalence of atrial fibrillation (AF) is bound to increase globally in the following years, affecting the quality of life of millions of people, increasing mortality and morbidity, and beleaguering health care systems. Increasingly effective therapeutic options against AF are the constantly evolving electroanatomic substrate mapping systems of the left atrium (LA) and ablation catheter technologies. Yet, a prerequisite for better long-term success rates is the understanding of AF pathogenesis and maintenance. LA electrical and anatomical remodeling remains in the epicenter of current research for novel diagnostic and treatment modalities. On a molecular level, electrical remodeling lies on impaired calcium handling, enhanced inwardly rectifying potassium currents, and gap junction perturbations. In addition, a wide array of profibrotic stimuli activates fibroblast to an increased extracellular matrix turnover via various intermediaries. Concomitant dysregulation of the autonomic nervous system and the humoral function of increased epicardial adipose tissue (EAT) are established mediators in the pathophysiology of AF. Local atrial lymphomononuclear cells infiltrate and increased inflammasome activity accelerate and perpetuate arrhythmia substrate. Finally, impaired intracellular protein metabolism, excessive oxidative stress, and mitochondrial dysfunction deplete atrial cardiomyocyte ATP and promote arrhythmogenesis. These overlapping cellular and molecular alterations hinder us from distinguishing the cause from the effect in AF pathogenesis. Yet, a plethora of therapeutic modalities target these molecular perturbations and hold promise in combating the AF burden. Namely, atrial selective ion channel inhibitors, AF gene therapy, anti-fibrotic agents, AF drug repurposing, immunomodulators, and indirect cardiac neuromodulation are discussed here.
\end{abstract}

Keywords: atrial fibrillation pathophysiology; rotors and focal impulses; fibrosis; extracellular matrix; fibroblasts; calcium homeostasis; inwardly rectifying potassium current; connexins; epicardial adipose tissue; autonomic nervous system; inflammasome; immune cells; chemokines; oxidative stress; ATP depletion; mitochondrial oxidative phosphorylation; derailed proteostasis; adenosine monophosphate-regulated protein kinase; therapeutic implications

\section{Introduction}

Cardiac senescence, largely attributed to aging, hypertension, obesity, as well as genetic predisposition, has been associated with atrial fibrillation (AF) genesis and progres- 
sion [1]. AF is expected to affect 6-16 million individuals in the United States, 14 million in Europe, and 72 million in Asia by 2050 [2], imposing a surge with economic and social implications for the public health care systems.

One out of three patients with AF will develop heart failure, and 20-30\% of ischemic strokes are attributed to AF, increasing morbidity and mortality [3].

Almost four centuries have elapsed since 1628 when William Harvey was probably the first to describe AF in animals [4]. Nowadays, different ablation strategies have revolutionized AF treatment. However, a "ceiling" for more durable long-term success (strictly defined as no occurrence of AF) seems to be reached. Success rates range between 65 and 78\%, requiring an in-depth understanding of mechanistic links [5].

This narrative review aims to summarize fundamental aspects pertaining to AF pathophysiology in humans. Therapeutic implications are also discussed.

\section{Atrial Fibrillation Pathogenesis}

\subsection{Mechanistic Approach}

Increased focal atrial triggered activity, mainly due to delayed afterdepolarizations (DADs) and micro-reentrant circuits are the main electrophysiological mechanisms in all types of AF (paroxysmal, persistent, and permanent) [6].

In 1998, Haïssaguerre M et al. suggested that pulmonary vein (PV) ectopic activity is implicated in AF pathogenesis, paving the way for pivotal ablative therapeutic modalities such as pulmonary vein isolation (PVI) [7]. Abnormal atrial repolarization (exaggerated beat-to-beat oscillations in action potential duration [APD]) and decreased atrial conduction are shown to mitigate re-entry in patients with AF $[8,9]$.

A frequency-domain approach, utilized to explain AF initiation and maintenance, underscores that AF mechanistic links might be less chaotic than originally thought. In particular, focal impulse and rotor modulation (FIRM) mapping has already achieved a "panoramic" bi-atrial view and suggests that a small number of stable high-frequency re-entrant sources (rotors) perpetuate AF fibrillatory waves. This spatiotemporally ordered AF substrate was successfully targeted via FIRM-guided ablation with salutary long-term effects in CONFIRM and RADAR AF trials [10,11]. Yet, two recent meta-analyses report discordant results regarding the benefit of a combined AF rotors ablation and PVI as opposed to PVI alone [12,13].

\subsection{Molecular Pathophysiology}

\subsubsection{Ionic Perturbations}

The study of electric remodeling in human atria focuses, mainly, on altered calcium kinetics, impaired inwardly rectifying potassium currents, and gap junction changes.

Abnormal intracellular calcium $\left(\mathrm{Ca}^{2+}\right)$ handling is critical in triggering DADs and thus increased atrial ectopic activity. In human AF models, enhanced spontaneous sarcoplasmic reticulum (SR) $\mathrm{Ca}^{2+}$ release has been attributed to ryanodine receptor (RyR2) dysregulation [14,15], $\mathrm{Ca}^{2+} /$ calmodulin-dependent protein kinase-II (CaMKII) hyperactivity [16-18], or SPEG (striated muscle preferentially expressed protein kinase), a regulator of RyR2 phosphorylation and downregulation [19].

L-type Ca [2] current $\left(\mathrm{I}_{\mathrm{Ca}, \mathrm{L}}\right)$ attenuation leads to atrial APD shortening and seems to be implicated in AF maintenance $[20,21]$. An effect is at least partially driven by microRNA21 and microRNA-328 in humans [22,23]. Early re-activation of $\mathrm{I}_{\mathrm{Ca}, \mathrm{L}}$ current can also lead to early afterdepolarizations (EADs) and AF initiation [24]. Interestingly, impaired calcium homeostasis in human cardiomyocytes leads to inositol-trisphosphate-receptor (IP3R)/CAMKII signaling, which in turn decrease $\mathrm{I}_{\mathrm{Ca}, \mathrm{L}}$ density [25].

Inwardly rectifying potassium (Kir) current $\left(\mathrm{I}_{\mathrm{K} 1}\right)$ as well as acetylcholine-activated potassium current $\left(\mathrm{I}_{\mathrm{K}, \mathrm{Ach}}\right)$ are enhanced in AF patients and shorten atrial APD [26,27]. MicroRNA-26 and microRNA-1 downregulation leads to increased Kir2.1 protein expression and establishes atrial re-entry via $\mathrm{I}_{\mathrm{K} 1}$ current activation $[28,29]$. Both $\mathrm{I}_{\mathrm{K} 1}$ and $\mathrm{I}_{\mathrm{K} \text {,Ach }}$ currents are critically involved in maintaining a left-to-right dominant frequency gradi- 
ent in paroxysmal AF (PAF) subjects and explain AF drivers formation (rotors and focal impulses) [30].

Cardiac connexins create gap junctions, facilitating cell-to-cell electrical and molecular signaling [31]. Ultra-structural changes of atrial connexins are noticed in human AF experiments. Connexin-43 (Cx43) dysregulation is present in the atria of AF patients [32] and seems to be regulated through interplay between microRNA-613 and long noncoding RNA HOTAIR (HOX transcript antisense RNA) [33]. Connexin-40 (Cx40) is mainly found in the atrial myocardium and is associated with AF development, as shown in various genetic analyses [34-36]. Increased lateralization and hyperphosphorylation of either Cx43 or Cx40 are implicated in human AF pathophysiology [37-39].

\subsubsection{Structural Changes}

Atrial fibrosis is the result of increased fibroblast activity with heterogeneous patchy areas of collagen type I depositions. This favors longer AF periods, LA enlargement, distortion of intercellular electrical coupling, and perpetuation of AF fibrillatory waves [40].

Of note, delicate 3D human atria models suggested that fibrosis reduces atrial conduction velocity and stabilizes rotors and re-entrant circuits [41]. A study including patients with persistent $\mathrm{AF}$, who underwent LA tissue characterization with MRI scans and concomitant high-density mapping of the LA, demonstrated increased AF rotor activity in areas of relatively low and patchy late-gadolinium enhancement (LGE) [42]. Bioinformatics' analysis has recently revealed that LA-PV junction demonstrates distinct gene expression differences in AF patients as compared to sinus rhythm (SR) controls, favoring extracellular matrix (ECM) synthesis and chemokine up-regulation [43].

TGF- $\beta$ signaling is strongly associated with these structural changes [44]. Various microRNAs and long noncoding RNAs seem to regulate cardiac fibroblast profibrogenic activity [45-49]. A recently discovered crosstalk between Slit2-Robo1 and TGF- $\beta 1 /$ Smad pathways promises potential therapeutic targets against atrial fibrosis [50].

Furthermore, platelet-derived TGF- $\beta$ secretion stimulates fibroblast proliferation, setting a vicious cycle of atrial fibrosis [51]. Platelet-derived growth factor (PDGF) also leads to increased cardiac fibroblast activity [52] and eventually to atrial fibrosis [53].

Mitogen-activated protein kinase 1 (MAPK1) overexpression, evident in cardiac fibroblast from AF patients, stimulates collagen deposition. An effect that can be mitigated by microRNA-450a-2-3p [54].

Angiotensin II (Ang II) is also known to induce critical ECM changes (increased collagen deposition and metalloproteinase activity) via JAK/STAT3 molecular pathway [55]. Ang II receptor type 1 (AT1) is up-regulated in the LA of subjects suffering AF [56]. Inhibition of AT1 restores intracellular calcium homeostasis and prevents arrhythmogenesis [57]. In addition, fibroblast growth factor 23 (FGF23) is involved in atrial fibrogenesis via increased oxidative stress and STAT3/SMAD3 signaling [58].

Connective tissue growth factor (CTGF) levels in human atrial fibroblasts and epicardial adipose tissue (EAT) are positively correlated with atrial fibrosis and AF arrhythmogenesis [59,60]. MicroRNA-132 and Ang II regulate CTGF levels in human atria [61,62].

Finally, atrial tissue calcitonin levels are inversely correlated with atrial arrhythmogenesis. A recent study suggested that calcitonin halts cardiac fibroblast overactivity and prevents ECM turnover [63].

Apart from generating a fibrotic substrate, cardiac fibroblasts affect cell-to-cell electrical coupling and exhibit altered electrophysiological properties in humans suffering from AF compared to SR controls [64]. This finding necessitates further evaluation, especially in the light of mechanistic data suggesting that fibroblast proliferation leads to complex fractionated atrial electrograms (CFAEs) genesis [65] and action potential propagation block in pulmonary veins [66]. 


\subsubsection{Epicardial Adipose Tissue (EAT) and Autonomic Nervous System (ANS)}

From a mechanistic point of view, the EAT in patients with persistent AF (PeAF) seems to be related to rotors capable of maintaining $\mathrm{AF}$ [67] and positively associated with low voltage areas, reduced conduction velocity, and CFAE [68,69].

EAT is a known cause of electrophysiological changes, such as heterogeneous atrial conduction slowing. These alterations have been attributed to $C \times 40$ lateralization, excessive fibrosis, and heterogeneous adipose infiltration of the affected atria [70].

Interestingly, a unique molecular footprint has recently been shown in EAT from AF subjects. In particular, EAT derived extracellular vesicles (EVs) exert profibrotic/ proinflammatory effects on the neighboring atrial tissue, promoting arrhythmogenesis [71]. In addition, EAT expansion seems to be positively regulated through increased atrial natriuretic peptide (ANP) levels [72].

EAT is metabolically active, and paracrine secretion of inflammatory mediators (IL- $1 \beta$, among others) $[73,74]$ is associated with atrial fibrillation in humans [75].

EAT-mediated atrial fibrosis has been linked to the PeAF subtype, and $\mathrm{CD}^{+}$lymphocyte infiltrates are seemingly involved [76]. Angiopoietin-like protein 2 (Angpt12), YKL-40, CTGF, activin A (TGF- $\beta$ superfamily) upregulation and Omentin-1 downregulation in human EAT are also implicated in atrial fibrosis and AF development [60,77-80].

Intrinsic cardiac ANS is organized in a network of ganglionated plexi (GP), which are accommodated in EAT, mainly around PVs [81].

Various methods of cardiac ANS assessment (heart rate variability, [82,83] skin sympathetic nerve activity [84], metaiodobenzylguanidine (MIBG) scintigraphy [85]) imply that ANS instability is implicated in human AF pathogenesis.

The clinical impact of ANS modulation (GP ablation in addition to PVI in patients with PAF [86], chemical; botulinum toxin [87,88] or calcium chloride [89]; autonomic denervation in cardiac surgery patients, transcutaneous vagal nerve stimulation [90]) in managing AF further strengthens the role of autonomic remodeling in AF pathophysiology, and it is further discussed in Section 3: Therapeutic Perspectives.

\subsubsection{The Role of Inflammation}

Local inflammation is apparent in AF pathophysiology since human LA tissue examination has revealed an infiltrate of varying immune cells (neutrophils, proinflammatory $\mathrm{CD}^{+} 8^{+}$macrophages, $\mathrm{CD} 8^{+}$and $\mathrm{CD}^{+}$lymphocytes) in AF subjects [91-94].

IL-6 secretion seems to be a critical mediator in suppressing regulatory $\mathrm{T}$ cell function and triggering atrial fibrosis [95]. In addition, macrophage migration inhibitory factor (MIF) release, an early mediator in inflammation cascade, was previously shown to suppress $\mathrm{I}_{(\mathrm{Ca}, \mathrm{L})}$ current and is also associated with AF genesis [96].

Serum levels of Interleukin-2 soluble receptor and TNF- $\alpha$ soluble receptor are among the stronger predictors of new-onset $\mathrm{AF}$, as assessed via machine learning algorithms in Multi-Ethnic Study of Atherosclerosis (MESA) [97]. This observation is in accordance with other indices of systematic inflammation (TNF- $\alpha$, hs-CRP, IL-6, IL-8, and IL-18) [98-101], all of which are up-regulated in the serum of patients with AF. These findings suggest the interplay of an atrial-specific and systematic hyperinflammatory state in AF subjects. Additionally, elevated baseline hs-CRP levels independently predicted arrhythmia recurrence post-ablation and are positively associated with low LA voltage areas, rotors, and non-PV ectopic foci [102].

NLRP3 (NACHT, LRR, and PYD domain-containing protein 3) inflammasome activity is also enhanced in atrial cardiomyocytes from AF patients and brings about electroanatomic remodeling [103]. Post-operative AF (POAF) patients were shown to express a higher level of the activated inflammasome in their atrial tissue, an observation linked to enhanced spontaneous SR Ca ${ }^{2+}$ release and DADs formation [104].

From a clinical perspective, recent evidence suggests that immunomodulatory agents, such as corticosteroids and colchicine, have a preventive role in POAF development [105-108] and support the fundamental role of inflammatory pathways in managing AF. 


\subsubsection{The Role of Proteostasis, Oxidative Stress, and Mitochondrial Bioenergetics}

The role of metabolic stress is increasingly recognized in AF pathophysiology, and it is discussed below in view of impaired protein cycling, oxidative stress, and mitochondrial dysfunction.

Proteostasis is defined as the balance between protein synthesis, folding, and degradation [109]. Impaired protein homeostasis is observed in human cellular aging as well as in cardiac diseases [110]. Derailed proteostasis exhibited through heat shock proteins (HSPs) up-regulation, calpain hyperactivity, and autophagosome formation is involved in AF genesis.

HSPs are produced as a response to cellular stress and stabilize other intracellular proteins. HSP27 was previously shown to be up-regulated in the atria of PAF patients and attenuates stress-induced structural changes (myolysis) [111]. In addition, low baseline HSP27 is associated with low LA voltage areas, non-PV foci, and decreased arrhythmia free intervals in patients undergoing ablation for PAF [112]. A more recent study suggests that post-ablation rise in serum HSP27 levels are predictive of arrhythmia recurrence, while baseline levels of different HSPs are of no clinical significance, thus creating a need for further research [113].

Atrial tissue from PeAF patients demonstrates increased macroautophagy (a process of autophagosome formation and eventually lysosomal degradation of damaged proteins), which is linked to reduced $\mathrm{I}_{(\mathrm{Ca}, \mathrm{L})}$ current and atrial APD shortening in animal studies [114].

Calpain I (a non-lysosomal proteolytic enzyme) activity is enhanced in atrial myocytes of both PAF and PeAF patients and has been linked with APD shortening [115]. Histone deacetylase 6 (HDAC6) hyperactivity, evident in human AF atria, disrupts cytoskeleton (microtubules) and culminates in increased $\alpha$-tubulin degradation by calpains [116]. Recently, HDAC6 up-regulation was proven capable of triggering atrial fibrosis and Cx lateralization in a rat AF model [117].

In PeAF patients, increased markers of DNA damage were positively associated with poly(ADP-ribose) polymerase (PADP) levels and hint an energy-deficient state. In particular, the physiologic cellular process of DNA repair sometimes leads to exaggerated PADP activity and nicotinamide adenine dinucleotide $\left(\mathrm{NAD}^{+}\right)$depletion, which in turn confers oxidative stress and progressive ATP decline [118].

Additionally, increased production of reactive oxygen species (ROS) is implicated in human AF via both local (atrial cardiomyocyte) and systematic (serum) nicotinamideadenine dinucleotide phosphate oxidase (NOX) activity $[119,120]$. Low levels of DNA oxidative stress markers in serum or urine from AF patients have been associated with prolonged arrhythmia-free survival [121,122].

Finally, mitochondrial energy production is critically affected in AF patients since reduced oxidative phosphorylation and increased mitochondrial fragmentation lead to ATP depletion $[123,124]$. POAF patients are also known to exhibit impaired oxidative phosphorylation capacity pre-operatively [125].

Long noncoding RNAs might be involved in mitochondrial bioenergetics, regulating ATP synthase and CYP450 enzymes [126]. Mitochondrial dysfunction is postulated to induce electrical remodeling via oxidative dysfunction of RyR2 [127].

Adenosine monophosphate-regulated protein kinase (AMPK) activity demonstrates a compensatory increase as a response to AF-induced metabolic stress, restoring calcium homeostasis [128], and it is suggested to be a novel therapeutic target.

Evidently, AF pathogenesis involves overlapping cellular and molecular perturbations that hinder us from distinguishing the cause from the effect (see Appendix A). Since gauging the critical importance of any single mechanism in different clinical AF subtypes is both impractical and unsettled, many therapeutic strategies target multiple mechanisms and seem promising, as discussed in the following section. 


\section{Therapeutic Perspectives}

\subsection{Atrial Selective Ion Channel Inhibitors and Gene Therapy}

The limited efficacy of current antiarrhythmic drugs in parallel with their pro-arrhythmic potential and their contraindication in the presence of structural heart diseases dictate the employment of atrial selective anti-AF molecular targets.

A computer-simulated (in silico) model of human AF has recently tested the combination of PVI and $\mathrm{I}_{\mathrm{K}, \mathrm{Ach}}$ blockade against AF development and suggested that this strategy remains highly effective even in cases of severe atrial fibrosis [129].

Niferidil was shown to prolong atrial APD in a porcine model of AF, an effect attributed to $I_{K, A c h}$ and $I_{K, r}$ (delayed rectifier potassium current) inhibition [130]. A sheep model of AF demonstrated that chloroquine exerts anti-AF effects via $\mathrm{I}_{\mathrm{K}, \mathrm{Ach}}$ channel blockade [131]. An equine AF model revealed that XAF-1407, a potent and selective $I_{K, A c h}$ inhibitor, is a safe and effective means of AF cardioversion [132]. This observation is in accordance with Sobota V et al., showing that XAF-1407 demonstrates superior cardioversion efficacy than vernakalant in a goat model of AF [133].

Pentamidine analogue 6 (PA-6) is a synthetic and selective $\mathrm{I}_{\mathrm{K} 1}$ inhibitor capable of restoring sinus rhythm in goats suffering from $\mathrm{AF}$, and it is also known to block $\mathrm{I}_{\mathrm{K} 1}$ current in human atria [134].

The tandem of $\mathrm{P}$ domains in a weak inward rectifying $\mathrm{K}^{+}$channel (TWIK)-related acid-sensitive $\mathrm{K}^{+}$channel (TASK-1) is implicated in atrial fibrillation genesis via atrial APD shortening. TASK-1 current inhibition through either siRNA (small interfering RNA) [135] or high-affinity antagonist A293 [136] represent a novel antiarrhythmic strategy. Furthermore, doxapram, a respiratory stimulant and TASK-1 inhibitor, was effective in reducing AF burden in a porcine model of persistent AF [137].

Undeniably, the above-mentioned atrial selective antiarrhythmic substances hold promise in the future pharmacopoeia against AF, yet translational discrepancies must be kept in mind when evaluating novel antiarrhythmic targets. Previous studies have failed to confirm the preclinical antiarrhythmic efficacy of $I_{K, A c h}$ inhibition in human subjects [138]. Additionally, XEN-D0103 (an atrial selective inhibitor of the Kv1.5 channel, which mediates ultra-rapid delayed rectifier current $\left(\mathrm{I}_{\mathrm{Kur}}\right)$ [139]) failed to reduce AF burden in PAF subjects [140].

AF gene therapy is still in its infancy, yet promising evidence is constantly accumulating. Following epicardial delivery of HERG-G628S, a dominant-negative mutant of the $\mathrm{I}_{\mathrm{Kr}}$ channel, porcine atria demonstrated APD prolongation and reduced AF susceptibility [141-144].

Cx43 gene transfer to porcine atria through epicardial electroporation has been found effective in preventing AF development [145]. Epicardial transfer of Cx40 and Cx43 genes also prevented AF episodes in a swine model of AF via atrial conduction improvement [146].

In a canine model of AF, epicardial delivery of the angiotensin-converting enzyme2 (ACE2) gene was associated with reduced AF inducibility due to a positive effect on electrophysiological properties of atrial fibroblasts [147].

\subsection{Drug Repurposing}

Drug repurposing has been employed in combating the AF burden and evidently offers good prospects.

Vanoxerine is an oral multi-ion channel blocker $\left(\mathrm{I}_{\mathrm{Na}}, \mathrm{I}_{\mathrm{Kr}}, \mathrm{I}_{\mathrm{Ca}, \mathrm{L}}\right)$ effective in terminating recent-onset $\mathrm{AF}$, yet the two available randomized placebo-controlled trials (RCTs) reported discordant safety results. In COR-ART, no ventricular proarrhythmia was noticed [148], while RESTORE SR was prematurely terminated due to increased incidence of torsades de pointes ventricular tachyarrhythmia in the vanoxerine arm [149]. A recent pharmacodynamics study highlights that vanoxerine possesses poor atrial selectivity, prolongs ventricular repolarization, and increases intracellular calcium overload risk, thus rendering future investigations unlikely [150]. 
Antazoline is an anti-histaminic drug that has also been repurposed for AF management due to its multi-ionic effects and has shown effectiveness in AF cardioversion during PVI [151,152]. In addition, a small RCT of 74 paroxysmal AF subjects (AnPAF study) demonstrated that intravenous antazoline is effective in rapid cardioversion of AF [153]. A retrospective case-control study $(N=334)$ suggests that antazoline antiarrhythmic potential is maintained in coronary artery disease patients without safety concerns [154]. CANT study, a retrospective observational study of $450 \mathrm{AF}$ patients treated with pharmacologic cardioversion in the emergency department, showed that antazoline is superior to amiodarone and at least as effective as propafenone [155]. The effectiveness of antazoline in AF cardioversion is also supported by a recent meta-analysis (odds ratio: $24.9 ; 95 \%$ credible interval: 7.4-107.8) [156].

Ivabradine is an inhibitor of $\mathrm{I}_{\mathrm{f}}$ current, and it is currently approved for the treatment of angina and heart failure. Apart from the sinus node, $\mathrm{I}_{\mathrm{f}}$ channels are present in the atrioventricular node ( $\mathrm{AV}$ node), and $\mathrm{I}_{\mathrm{f}}$ current inhibition can slow $\mathrm{AV}$ node conduction in animal studies [157].

Ventricular rate control was achieved after ivabradine administration in a small case series of 6 paroxysmal or persistent AF patients on a maximally tolerated dose of betablocker [158]. Wongcharoen $\mathrm{W}$ et al. conducted a small RCT ( $N=32$ non-paroxysmal AF subjects) and found that after one month of ivabradine administration, the mean ventricular rate was significantly decreased, as assessed via 24-hour Holter [159].

BRAKE-AF project will compare ivabradine to digoxin in 232 patients with permanent $\mathrm{AF}$ and poor rate control despite beta-blocker or calcium channel blocker administration [160]. A meta-analysis of three RCTs (36,577 participants) suggests that ivabradine administration is associated with symptomatic bradycardia and atrial fibrillation (OR: 6.23; CI: 4.2-9.26; $p<0.00001$ and OR: 1.35; CI: 1.19-1.53; $p<0.0001$, respectively) [161]. Before putting ivabradine to the test against rate control, these findings necessitate further elucidation.

Dantrolene inhibits sarcoplasmic calcium release in skeletal muscle cells, and it is indicated in malignant hyperthermia. A favorable anti-AF effect has been observed in various preclinical settings such as rat models of heart failure [162], hypertension [163], and autonomic nervous system imbalance [164,165]. A canine model of tachypaced AF further supports dantrolene's antiarrhythmic potential, and RyR2 channel stabilization is the underlying antiarrhythmic mechanism [166]. RyR2 channels from human atrial cardiomyocytes were also positively affected after in vitro dantrolene treatment [167].

\subsection{Anti-Fibrotic Agents}

Finerenone, a novel mineralocorticoid receptor antagonist, was recently shown to exert antiarrhythmic effects. In particular, the FIDELIO-DKD study evaluated 5,674 patients with chronic kidney disease (eGFR $\geq 25$ to $<75 \mathrm{~mL} / \mathrm{min} / 1.73 \mathrm{~m}^{2}$ ) and type 2 diabetes mellitus; approximately $8 \%$ had baseline atrial fibrillation or flutter; on secondary analysis, investigators found that finerenone administration is associated with $29 \%$ reduction in new atrial arrhythmic events (HR: $0.71 ; 95 \%$ confidence interval: $0.53-0.94 ; p=0.016$ ) after a median follow-up of 2.6 years. Of note, Kaplan-Meier curves separation became apparent at 6 months, which implies that structural remodeling reversal might be implicated in finerenone mediated AF prevention [168].

Relaxin is a human hormone belonging to the insulin superfamily and mediates vasodilation, angiogenesis, and hemodynamic changes during pregnancy. Animal studies support an anti-AF potential through fibrosis reversal. In particular, rat models of AF have shown that relaxin administration is associated with TGF- $\beta$, metalloproteinase-2, metalloproteinase-9, and collagen I/III downregulation, which in turn enhance atrial conduction velocity by reverting atrial structural remodeling $[169,170]$. Wnt-signaling was recently shown to mediate relaxin antiarrhythmic effects [171]. Of note, pre-ablation relaxin in serum levels independently predicts radiofrequency ablation outcomes in humans suffering paroxysmal or persistent AF [172]. Serelaxin, a recombinant form of human 
relaxin, was previously shown to be effective in alleviating dyspnea and reduce all-cause mortality in patients with acute heart failure irrespective of AF status [173]. Whether serelaxin exerts any antiarrhythmic effect, remains to be tested.

As previously discussed, TGF- $\beta$ /Smad signaling pathway is implicated in atrial fibrosis and represents a therapeutic molecular target. Recently, it was shown that recombinant human MFGE8 (milk fat globule-EGF factor 8) inhibits this pathway and alleviates structural remodeling in atriums of rats [174].

\subsection{Immunomodulators and AMPK Activators}

The inflammatory milieu is involved in both atherosclerosis and AF progression. CANTOS trial suggested that subcutaneous administration of canakinumab at a dose of $150 \mathrm{mg}$ every 3 months reduces the composite endpoint of nonfatal myocardial infarction, nonfatal stroke, or cardiovascular death (hazard ratio: $0.85 ; 95 \%$ CI: $0.74-0.98 ; p=0.021$ ) [175]. On the contrary, CONVERT-AF a small $(N=24)$ RCT evaluating a single dose of $150 \mathrm{mg}$ canakinumab $60 \mathrm{~h}$ after electrical cardioversion for persistent AF failed to reduce 6 month AF recurrence rates (hazard ratio: $0.36 ; 95 \%$ CI: 0.11-1.15; $p=0.09$ ) [176].

Colchicine, an inexpensive anti-inflammatory drug with pleiotropic cardioprotective effects [177], is known to reduce POAF incidence [178-180], and a recent cost-utility analysis solidifies the cost-effectiveness of this approach [181]. A 3-month scheme of $0.5 \mathrm{mg}$ of colchicine twice daily was previously shown effective in reducing post-ablation AF recurrence after a median follow-up of 15 months [182].

Derailed proteostasis leads to integrated stress response (ISR), which in turn triggers gene expression reprogramming and is implicated in the pathogenesis of many human diseases [183]. In a rat model of post-myocardial infraction AF, inhibition of intracellular stress response (small molecule ISRIB administration) led to AF prevention by halting electroanatomic remodeling, autophagy, and inflammation cascade [184]. In vitro tachypaced canine atrial cardiomyocytes display $\mathrm{I}_{\mathrm{K} \text {,Ach }}$ current enhancement, and calpain inhibition via PD150606 administration led to $\mathrm{I}_{\mathrm{K}, \mathrm{Ach}}$ current suppression and AF prevention [185].

Clinical observational data support that metformin lowers the risk of AF development in patients with diabetes mellitus type 2 [186] and could reduce AF recurrence postablation [187]. Preclinical data hint that metformin activates the AMPK pathway and leads to amelioration of mitochondrial dysfunction [188], impaired atrial bioenergetics [189], and connexin dysregulation [190].

Fisetin, a pleiotropic plant polyphenol, was recently tested in a rat AF model. Of note, fisetin treated rodents demonstrated reduced AF susceptibility due to reduced atrial inflammation and fibrosis [191]. AMPK and Smad signaling pathways mediated these effects and imply that simultaneous targeting of various AF molecular perturbations (inflammatory milieu, fibrosis, and bioenergetics) might be an efficacious strategy.

\subsection{Neuromodulation}

Autonomic neuromodulation is an evolving and promising AF therapeutic approach. Botulinum toxin injection into epicardial fat pads was shown effective in reducing postoperative AF episodes during a 3-year follow-up. Temporary interruption of intrinsic cardiac ANS overactivity restores autonomic imbalance and breaks the vicious cycle of AF begetting AF [88]. Interestingly, intermittent low level transcutaneous (ear tragus) vagal stimulation lowers AF burden in patients with paroxysmal AF at 6 months [90]. Again, electroanatomical remodeling reversal and anti-inflammatory effects are seemingly involved in this neuromodulatory strategy.

Furthermore, adiponectin administration into ganglionated plexi in a tachypached canine AF model was associated with AF suppression [192]. This study underscores that the crosstalk between EAT and ANS is a valid therapeutic target to AF and merits further investigation.

Indirect cardiac neuromodulation can also be achieved via renal sympathetic denervation (RDN). AFFORD study showed that patients with AF and hypertension undergoing 
RDN benefited in terms of blood pressure control and AF burden reduction [193]. A small $(N=432)$ meta-analysis by Atti V et al. demonstrated that RDN plus PVI is superior to PVI alone in reducing post-ablation arrhythmia recurrence in patients with $\mathrm{AF}$ (paroxysmal or persistent) and concomitant hypertension (RR: 0.58 ; 95\% CI: $0.47-0.72 ; p<0.00001$ ) [194].

The central sympatholytic agent moxonidine was previously shown effective in reducing AF burden in patients with paroxysmal AF [195] as well as 12-month arrhythmia recurrence rates following PVI for paroxysmal AF [196].

Multipulse Therapy (MPT) constitutes an intracardiac sequence of low-voltage, lowenergy stimulation pulses aiming to terminate AF episodes. The first human feasibility study showed $71 \%$ efficacy in terminating $\mathrm{AF}$ and paves the way for further investigations, with the ultimate goal being MPT implementation in cardiac devices (implantable cardioverter defibrillators and resynchronization cardiac therapies) [197].

\section{Conclusions}

Inflammatory milieu and metabolic stress (mitochondrial dysfunction and derailed proteostasis) are interlinked with the classic electroanatomic remodeling in human AF. The molecular mediators of these pathways should be targeted in order to combat AF pathogenesis. Hopefully, novel therapeutic approaches are underway, and clinical data are much awaited.

Funding: No funding source was utilized for this review article.

Conflicts of Interest: The authors declare no conflict of interest.

\section{Appendix A}

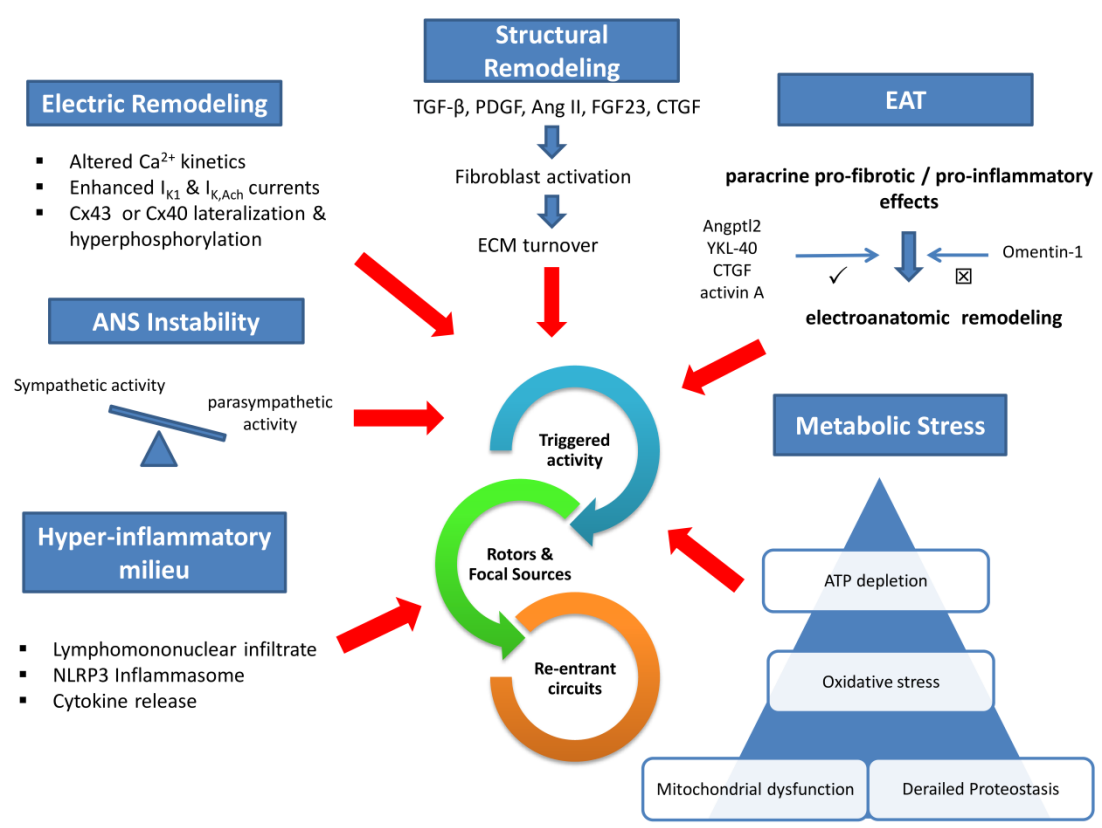

Figure A1. Central Illustration Legend: Six overlapping and interlinked (not shown) pathways are implicated in atrial fibrillation pathophysiology: electric remodeling, structural remodeling, autonomic instability, hyperinflammatory milieu, metabolic stress, and epicardial adipose tissue paracrine effects. The common endpoint is the initiation and maintenance of arrhythmic events. $\mathrm{I}_{\mathrm{K} 1}-$ inwardly rectifying potassium current; $\mathrm{I}_{\mathrm{K}, \mathrm{Ach}}$ - acetylcholine-activated potassium current; ANSautonomic nervous system; $\mathrm{Cx}$-connexin; TGF- $\beta$ — tissue growth factor $\beta$; PDGF-platelet-derived growth factor; AngII-angiotensin II; FGF23 - fibroblast growth factor 23; CTGF-connective tissue growth factor; ECM-extracellular matrix; EAT—epicardial adipose tissue; Angpt12-angiopoietinlike protein 2. 


\section{References}

1. Hobbelt, A.H.; Siland, J.E.; Geelhoed, B.; Van Der Harst, P.; Hillege, H.L.; Van Gelder, I.C.; Rienstra, M. Clinical, biomarker, and genetic predictors of specific types of atrial fibrillation in a community-based cohort: Data of the PREVEND study. EP Eur. 2017, 19, 226-232. [CrossRef]

2. Kornej, J.; Börschel, C.S.; Benjamin, E.J.; Schnabel, R.B. Epidemiology of Atrial Fibrillation in the 21st Century. Circ. Res. 2020, 127, 4-20. [CrossRef]

3. Hindricks, G.; Potpara, T.; Dagres, N.; Arbelo, E.; Bax, J.J.; Blomström-Lundqvist, C.; Boriani, G.; Castella, M.; Dan, G.-A.; Dilaveris, P.E.; et al. 2020 ESC Guidelines for the diagnosis and management of atrial fibrillation developed in collaboration with the European Association of Cardio-Thoracic Surgery (EACTS). Eur. Heart J. 2020, 42, 373-498. [CrossRef]

4. Khasnis, A.; Thakur, R.K. Atrial Fibrillation: A Historical Perspective. Cardiol. Clin. 2009, 27, 1-12. [CrossRef]

5. Perino, A.C.; Leef, G.C.; Cluckey, A.; Yunus, F.N.; Askari, M.; Heidenreich, P.A.; Narayan, S.M.; Wang, P.J.; Turakhia, M.P. Secular trends in success rate of catheter ablation for atrial fibrillation: The SMASH-AF cohort. Am. Heart J. 2019, 208, 110-119. [CrossRef]

6. Burashnikov, A. Investigational Anti-Atrial Fibrillation Pharmacology and Mechanisms by Which Antiarrhythmics Terminate the Arrhythmia: Where Are We in 2020? J. Cardiovasc. Pharmacol. 2020, 76, 492-505. [CrossRef] [PubMed]

7. Haïssaguerre, M.; Jaïs, P.; Shah, D.C.; Takahashi, A.; Hocini, M.; Quiniou, G.; Garrigue, S.; Le Mouroux, A.; Le Métayer, P.; Clémenty, J. Spontaneous Initiation of Atrial Fibrillation by Ectopic Beats Originating in the Pulmonary Veins. N. Engl. J. Med. 1998, 339, 659-666. [CrossRef] [PubMed]

8. Lalani, G.G.; Schricker, A.; Gibson, M.; Rostamian, A.; Krummen, D.E.; Narayan, S.M. Atrial Conduction Slows Immediately Before the Onset of Human Atrial Fibrillation. J. Am. Coll. Cardiol. 2012, 59, 595-606. [CrossRef] [PubMed]

9. Narayan, S.M.; Franz, M.R.; Clopton, P.; Pruvot, E.J.; Krummen, D.E. Repolarization Alternans Reveals Vulnerability to Human Atrial Fibrillation. Circulation 2011, 123, 2922-2930. [CrossRef]

10. Narayan, S.M.; Baykaner, T.; Clopton, P.; Schricker, A.; Lalani, G.G.; Krummen, D.E.; Shivkumar, K.; Miller, J.M. Ablation of Rotor and Focal Sources Reduces Late Recurrence of Atrial Fibrillation Compared with Trigger Ablation Alone. J. Am. Coll. Cardiol. 2014, 63, 1761-1768. [CrossRef]

11. Atienza, F.; Almendral, J.; Ormaetxe, J.M.; Moya, Á.; Martínez-Alday, J.D.; Hernández-Madrid, A.; Castellanos, E.; Arribas, F.; Arias, M.Á.; Tercedor, L.; et al. Comparison of Radiofrequency Catheter Ablation of Drivers and Circumferential Pulmonary Vein Isolation in Atrial Fibrillation. J. Am. Coll. Cardiol. 2014, 64, 2455-2467. [CrossRef]

12. Mohanty, S.; Mohanty, P.; Trivedi, C.; Gianni, C.; Della Rocca, D.G.; Di Biase, L.; Natale, A. Long-Term Outcome of Pulmonary Vein Isolation with and Without Focal Impulse and Rotor Modulation Mapping. Circ. Arrhythmia Electrophysiol. 2018, 11, e005789. [CrossRef]

13. Baykaner, T.; Rogers, A.J.; Meckler, G.L.; Zaman, J.; Navara, R.; Rodrigo, M.; Alhusseini, M.; Kowalewski, C.A.B.; Viswanathan, M.N.; Narayan, S.M.; et al. Clinical Implications of Ablation of Drivers for Atrial Fibrillation. Circ. Arrhythmia Electrophysiol. 2018, 11, e006119. [CrossRef] [PubMed]

14. Voigt, N.; Heijman, J.; Wang, Q.; Chiang, D.Y.; Li, N.; Karck, M.; Wehrens, X.H.T.; Nattel, S.; Dobrev, D. Cellular and Molecular Mechanisms of Atrial Arrhythmogenesis in Patients with Paroxysmal Atrial Fibrillation. Circulation 2014, 129, 145-156. [CrossRef] [PubMed]

15. Vest, J.A.; Wehrens, X.H.T.; Reiken, S.R.; Lehnart, S.E.; Dobrev, D.; Chandra, P.; Danilo, P.; Ravens, U.; Rosen, M.R.; Marks, A.R. Defective Cardiac Ryanodine Receptor Regulation During Atrial Fibrillation. Circulation 2005, 111, 2025-2032. [CrossRef]

16. Voigt, N.; Li, N.; Wang, Q.; Wang, W.; Trafford, A.W.; Abu-Taha, I.; Sun, Q.; Wieland, T.; Ravens, U.; Nattel, S.; et al. Enhanced Sarcoplasmic Reticulum $\mathrm{Ca}^{2+}$ Leak and Increased $\mathrm{Na}^{+}-\mathrm{Ca}^{2+}$ Exchanger Function Underlie Delayed Afterdepolarizations in Patients with Chronic Atrial Fibrillation. Circulation 2012, 125, 2059-2070. [CrossRef] [PubMed]

17. Neef, S.; Dybkova, N.; Sossalla, S.; Ort, K.R.; Fluschnik, N.; Neumann, K.; Seipelt, R.; Schöndube, F.A.; Hasenfuss, G.; Maier, L.S. CaMKII-Dependent Diastolic SR Ca ${ }^{2+}$ Leak and Elevated Diastolic Ca ${ }^{2+}$ Levels in Right Atrial Myocardium of Patients with Atrial Fibrillation. Circ. Res. 2010, 106, 1134-1144. [CrossRef]

18. Yan, J.; Zhao, W.; Thomson, J.K.; Gao, X.; DeMarco, D.M.; Carrillo, E.; Chen, B.; Wu, X.; Ginsburg, K.S.; Bakhos, M.; et al. Stress Signaling JNK2 Crosstalk with CaMKII Underlies Enhanced Atrial Arrhythmogenesis. Circ. Res. 2018, 122, 821-835. [CrossRef] [PubMed]

19. Campbell, H.M.; Quick, A.P.; Abu-Taha, I.; Chiang, D.Y.; Kramm, C.F.; Word, T.A.; Brandenburg, S.; Hulsurkar, M.; Alsina, K.M.; Liu, H.-B.; et al. Loss of SPEG Inhibitory Phosphorylation of Ryanodine Receptor Type-2 Promotes Atrial Fibrillation. Circulation 2020, 142, 1159-1172. [CrossRef]

20. Herraiz-Martínez, A.; Tarifa, C.; Jiménez-Sábado, V.; Llach, A.; Godoy-Marín, H.; Colino-Lage, H.; Nolla-Colomer, C.; CasabellaRamon, S.; Izquierdo-Castro, P.; Benítez, I.; et al. Influence of sex on intracellular calcium homoeostasis in patients with atrial fibrillation. Cardiovasc. Res. 2021. [CrossRef]

21. Christ, T.; Boknik, P.; Wöhrl, S.; Wettwer, E.; Graf, E.M.; Bosch, R.F.; Knaut, M.; Schmitz, W.; Ravens, U.; Dobrev, D. L-Type Ca ${ }^{2+}$ Current Downregulation in Chronic Human Atrial Fibrillation Is Associated With Increased Activity of Protein Phosphatases. Circulation 2004, 110, 2651-2657. [CrossRef] [PubMed]

22. Barana, A.; Matamoros, M.; Dolz-Gaitón, P.; Pérez-Hernández, M.; Amorós, I.; Núñez, M.; Sacristán, S.; Pedraz, Á.; Pinto, Á.; Fernández-Avilés, F.; et al. Chronic Atrial Fibrillation Increases MicroRNA-21 in Human Atrial Myocytes Decreasing L-Type Calcium Current. Circ. Arrhythmia Electrophysiol. 2014, 7, 861-868. [CrossRef] [PubMed] 
23. Lu, Y.; Zhang, Y.; Wang, N.; Pan, Z.; Gao, X.; Zhang, F.; Zhang, Y.; Shan, H.; Luo, X.; Bai, Y.; et al. MicroRNA-328 Contributes to Adverse Electrical Remodeling in Atrial Fibrillation. Circulation 2010, 122, 2378-2387. [CrossRef] [PubMed]

24. Kettlewell, S.; Saxena, P.; Dempster, J.; Colman, M.A.; Myles, R.C.; Smith, G.L.; Workman, A.J. Dynamic clamping human and rabbit atrial calcium current: Narrowing I CaL window abolishes early afterdepolarizations. J. Physiol. 2019, 597, 3619-3638. [CrossRef] [PubMed]

25. Qi, X.-Y.; Vahdati Hassani, F.; Hoffmann, D.; Xiao, J.; Xiong, F.; Villeneuve, L.R.; Ljubojevic-Holzer, S.; Kamler, M.; Abu-Taha, I.; Heijman, J.; et al. Inositol Trisphosphate Receptors and Nuclear Calcium in Atrial Fibrillation. Circ. Res. 2021, 128, 619-635. [CrossRef] [PubMed]

26. Dobrev, D.; Friedrich, A.; Voigt, N.; Jost, N.; Wettwer, E.; Christ, T.; Knaut, M.; Ravens, U. The G Protein-Gated Potassium Current $I_{\mathrm{K}, \mathrm{ACh}}$ Is Constitutively Active in Patients With Chronic Atrial Fibrillation. Circulation 2005, 112, 3697-3706. [CrossRef]

27. Biliczki, P.; Boon, R.A.; Girmatsion, Z.; Bukowska, A.; Ördög, B.; Kaess, B.M.; Hohnloser, S.H.; Goette, A.; Varró, A.; Moritz, A.; et al. Age-related regulation and region-specific distribution of ion channel subunits promoting atrial fibrillation in human left and right atria. EP Eur. 2019, 21, 1261-1269. [CrossRef]

28. Luo, X.; Pan, Z.; Shan, H.; Xiao, J.; Sun, X.; Wang, N.; Lin, H.; Xiao, L.; Maguy, A.; Qi, X.-Y.; et al. MicroRNA-26 governs profibrillatory inward-rectifier potassium current changes in atrial fibrillation. J. Clin. Investig. 2013, 123, 1939-1951. [CrossRef] [PubMed]

29. Girmatsion, Z.; Biliczki, P.; Bonauer, A.; Wimmer-Greinecker, G.; Scherer, M.; Moritz, A.; Bukowska, A.; Goette, A.; Nattel, S.; Hohnloser, S.H.; et al. Changes in microRNA-1 expression and IK1 up-regulation in human atrial fibrillation. Heart Rhythm 2009, 6, 1802-1809. [CrossRef]

30. Voigt, N.; Trausch, A.; Knaut, M.; Matschke, K.; Varró, A.; Van Wagoner, D.R.; Nattel, S.; Ravens, U.; Dobrev, D. Left-to-Right Atrial Inward Rectifier Potassium Current Gradients in Patients with Paroxysmal Versus Chronic Atrial Fibrillation. Circ. Arrhythmia Electrophysiol. 2010, 3, 472-480. [CrossRef]

31. Andelova, K.; Egan Benova, T.; Szeiffova Bacova, B.; Sykora, M.; Prado, N.J.; Diez, E.R.; Hlivak, P.; Tribulova, N. Cardiac Connexin-43 Hemichannels and Pannexin1 Channels: Provocative Antiarrhythmic Targets. Int. J. Mol. Sci. 2020, $22,260$. [CrossRef]

32. Adam, O.; Lavall, D.; Theobald, K.; Hohl, M.; Grube, M.; Ameling, S.; Sussman, M.A.; Rosenkranz, S.; Kroemer, H.K.; Schäfers, H.-J.; et al. Rac1-Induced Connective Tissue Growth Factor Regulates Connexin 43 and N-Cadherin Expression in Atrial Fibrillation. J. Am. Coll. Cardiol. 2010, 55, 469-480. [CrossRef] [PubMed]

33. Dai, W.; Chao, X.; Li, S.; Zhou, S.; Zhong, G.; Jiang, Z. Long Noncoding RNA HOTAIR Functions as a Competitive Endogenous RNA to Regulate Connexin43 Remodeling in Atrial Fibrillation by Sponging MicroRNA-613. Cardiovasc. Ther. 2020, 2020, 5925342. [CrossRef] [PubMed]

34. Christophersen, I.E.; Holmegard, H.N.; Jabbari, J.; Haunsø, S.; Tveit, A.; Svendsen, J.H.; Olesen, M.S. Rare Variants in GJA5 Are Associated With Early-Onset Lone Atrial Fibrillation. Can. J. Cardiol. 2013, 29, 111-116. [CrossRef] [PubMed]

35. Santa Cruz, A.; Meşe, G.; Valiuniene, L.; Brink, P.R.; White, T.W.; Valiunas, V. Altered conductance and permeability of Cx40 mutations associated with atrial fibrillation. J. Gen. Physiol. 2015, 146, 387-398. [CrossRef]

36. Wirka, R.C.; Gore, S.; Van Wagoner, D.R.; Arking, D.E.; Lubitz, S.A.; Lunetta, K.L.; Benjamin, E.J.; Alonso, A.; Ellinor, P.T.; Barnard, J.; et al. A Common Connexin-40 Gene Promoter Variant Affects Connexin-40 Expression in Human Atria and Is Associated with Atrial Fibrillation. Circ. Arrhythmia Electrophysiol. 2011, 4, 87-93. [CrossRef]

37. Nao, T.; Ohkusa, T.; Hisamatsu, Y.; Inoue, N.; Matsumoto, T.; Yamada, J.; Shimizu, A.; Yoshiga, Y.; Yamagata, T.; Kobayashi, S.; et al. Comparison of expression of connexin in right atrial myocardium in patients with chronic atrial fibrillation versus those in sinus rhythm. Am. J. Cardiol. 2003, 91, 678-683. [CrossRef]

38. Ghazizadeh, Z.; Kiviniemi, T.; Olafsson, S.; Plotnick, D.; Beerens, M.E.; Zhang, K.; Gillon, L.; Steinbaugh, M.J.; Barrera, V.; Sui, S.H.; et al. Metastable Atrial State Underlies the Primary Genetic Substrate for MYL4 Mutation-Associated Atrial Fibrillation. Circulation 2020, 141, 301-312. [CrossRef]

39. Dhein, S.; Rothe, S.; Busch, A.; Rojas Gomez, D.; Boldt, A.; Reutemann, A.; Seidel, T.; Salameh, A.; Pfannmüller, B.; Rastan, A.; et al. Effects of metoprolol therapy on cardiac gap junction remodelling and conduction in human chronic atrial fibrillation. Br. J. Pharmacol. 2011, 164, 607-616. [CrossRef] [PubMed]

40. Callegari, S.; Macchi, E.; Monaco, R.; Magnani, L.; Tafuni, A.; Croci, S.; Nicastro, M.; Garrapa, V.; Banchini, A.; Becchi, G.; et al. Clinicopathological Bird's-Eye View of Left Atrial Myocardial Fibrosis in 121 Patients with Persistent Atrial Fibrillation. Circ. Arrhythmia Electrophysiol. 2020, 13, e007588. [CrossRef]

41. Morgan, R.; Colman, M.A.; Chubb, H.; Seemann, G.; Aslanidi, O.V. Slow Conduction in the Border Zones of Patchy Fibrosis Stabilizes the Drivers for Atrial Fibrillation: Insights from Multi-Scale Human Atrial Modeling. Front. Physiol. 2016, 7, 474. [CrossRef]

42. Nakamura, T.; Kiuchi, K.; Fukuzawa, K.; Takami, M.; Watanabe, Y.; Izawa, Y.; Suehiro, H.; Akita, T.; Takemoto, M.; Sakai, J.; et al. Late-gadolinium enhancement properties associated with atrial fibrillation rotors in patients with persistent atrial fibrillation. $J$. Cardiovasc. Electrophysiol. 2021, 32, 1005-1013. [CrossRef]

43. Zou, R.; Yang, M.; Shi, W.; Zheng, C.; Zeng, H.; Lin, X.; Zhang, D.; Yang, S.; Hua, P. Analysis of Genes Involved in Persistent Atrial Fibrillation: Comparisons of 'Trigger' and 'Substrate' Differences. Cell. Physiol. Biochem. 2018, 47, 1299-1309. [CrossRef] 
44. Xiao, H.; Lei, H.; Qin, S.; Ma, K.; Wang, X. TGF- $\beta 1$ Expression and Atrial Myocardium Fibrosis Increase in Atrial Fibrillation Secondary to Rheumatic Heart Disease. Clin. Cardiol. 2010, 33, 149-156. [CrossRef] [PubMed]

45. Su, L.; Yao, Y.; Song, W. Downregulation of miR-96 suppresses the profibrogenic functions of cardiac fibroblasts induced by angiotensin II and attenuates atrial fibrosis by upregulating KLF13. Hum. Cell 2020, 33, 337-346. [CrossRef]

46. Yu, R.-B.; Li, K.; Wang, G.; Gao, G.-M.; Du, J.-X. MiR-23 enhances cardiac fibroblast proliferation and suppresses fibroblast apoptosis via targeting TGF- $\beta 1$ in atrial fibrillation. Eur. Rev. Med. Pharmacol. Sci. 2019, 23, 4419-4424. [CrossRef]

47. Xu, J.; Lei, S.; Sun, S.; Zhang, W.; Zhu, F.; Yang, H.; Xu, Q.; Zhang, B.; Li, H.; Zhu, M.; et al. MiR-324-3p Regulates Fibroblast Proliferation via Targeting TGF- $\beta 1$ in Atrial Fibrillation. Int. Heart J. 2020, 61, 1270-1278. [CrossRef] [PubMed]

48. Lu, J.; Xu, F.-Q.; Guo, J.-J.; Lin, P.-L.; Meng, Z.; Hu, L.-G.; Li, J.; Li, D.; Lu, X.-H.; An, Y. Long noncoding RNA GAS5 attenuates cardiac fibroblast proliferation in atrial fibrillation via repressing ALK5. Eur. Rev. Med. Pharmacol. Sci. 2019, 23, 7605-7610. [CrossRef]

49. Wang, H.; Song, T.; Zhao, Y.; Zhao, J.; Wang, X.; Fu, X. Long non-coding RNA LICPAR regulates atrial fibrosis via TGF- $\beta /$ Smad pathway in atrial fibrillation. Tissue Cell 2020, 67, 101440. [CrossRef] [PubMed]

50. Liu, Y.; Yin, Z.; Xu, X.; Liu, C.; Duan, X.; Song, Q.; Tuo, Y.; Wang, C.; Yang, J.; Yin, S. Crosstalk between the activated Slit2-Robo1 pathway and TGF- $\beta 1$ signalling promotes cardiac fibrosis. ESC Heart Fail. 2021, 8, 447-460. [CrossRef] [PubMed]

51. Liu, Y.; Lv, H.; Tan, R.; An, X.; Niu, X.-H.; Liu, Y.-J.; Yang, X.; Yin, X.; Xia, Y.-L. Platelets Promote Ang II (Angiotensin II)-Induced Atrial Fibrillation by Releasing TGF- $\beta 1$ (Transforming Growth Factor- $\beta 1$ ) and Interacting with Fibroblasts. Hypertension 2020, 76 , 1856-1867. [CrossRef] [PubMed]

52. Jiang, Z.; Zhong, G.; Wen, L.; Hong, Y.; Fang, S.; Sun, P.; Li, S.; Li, S.; Feng, G. The Role of Platelet-Derived Growth FactorB/Platelet-Derived Growth Factor Receptor- $\beta$ Signaling in Chronic Atrial Fibrillation. Cardiology 2016, 133, 242-256. [CrossRef] [PubMed]

53. Yang, D.; Yuan, J.; Liu, G.; Ling, Z.; Zeng, H.; Chen, Y.; Zhang, Y.; She, Q.; Zhou, X. Angiotensin Receptor Blockers and Statins Could Alleviate Atrial Fibrosis via Regulating Platelet-Derived Growth Factor/Rac1 /Nuclear Factor-Kappa B Axis. Int. J. Med. Sci. 2013, 10, 812-824. [CrossRef] [PubMed]

54. Liu, L.; Luo, F.; Lei, K. Exosomes Containing LINC00636 Inhibit MAPK1 through the miR-450a-2-3p Overexpression in Human Pericardial Fluid and Improve Cardiac Fibrosis in Patients with Atrial Fibrillation. Mediat. Inflamm. 2021, $2021,9960241$. [CrossRef]

55. Zheng, L.; Jia, X.; Zhang, C.; Wang, D.; Cao, Z.; Wang, J.; Du, X. Angiotensin II in atrial structural remodeling: The role of Ang II/JAK/STAT3 signaling pathway. Am. J. Transl. Res. 2015, 7, 1021-1031.

56. Boldt, A.; Wetzel, U.; Weigl, J.; Garbade, J.; Lauschke, J.; Hindricks, G.; Kottkamp, H.; Gummert, J.F.; Dhein, S. Expression of angiotensin II receptors in human left and right atrial tissue in atrial fibrillation with and without underlying mitral valve disease. J. Am. Coll. Cardiol. 2003, 42, 1785-1792. [CrossRef] [PubMed]

57. Gassanov, N.; Brandt, M.C.; Michels, G.; Lindner, M.; Er, F.; Hoppe, U.C. Angiotensin II-induced changes of calcium sparks and ionic currents in human atrial myocytes: Potential role for early remodeling in atrial fibrillation. Cell Calcium 2006, 39, 175-186. [CrossRef] [PubMed]

58. Dong, Q.; Li, S.; Wang, W.; Han, L.; Xia, Z.; Wu, Y.; Tang, Y.; Li, J.; Cheng, X. FGF23 regulates atrial fibrosis in atrial fibrillation by mediating the STAT3 and SMAD3 pathways. J. Cell. Physiol. 2019, 234, 19502-19510. [CrossRef]

59. Chen, J.; Guo, Y.; Chen, Q.; Cheng, X.; Xiang, G.; Chen, M.; Wu, H.; Huang, Q.; Zhu, P.; Zhang, J. TGF $\beta 1$ and HGF regulate CTGF expression in human atrial fibroblasts and are involved in atrial remodelling in patients with rheumatic heart disease. J. Cell. Mol. Med. 2019, 23, 3032-3039. [CrossRef]

60. Wang, Q.; Xi, W.; Yin, L.; Wang, J.; Shen, H.; Gao, Y.; Min, J.; Zhang, Y.; Wang, Z. Human Epicardial Adipose Tissue cTGF Expression is an Independent Risk Factor for Atrial Fibrillation and Highly Associated with Atrial Fibrosis. Sci. Rep. 2018, 8, 3585. [CrossRef] [PubMed]

61. Qiao, G.; Xia, D.; Cheng, Z.; Zhang, G. miR-132 in atrial fibrillation directly targets connective tissue growth factor. Mol. Med. Rep. 2017, 16, 4143-4150. [CrossRef]

62. Ko, W.-C.; Hong, C.-Y.; Hou, S.-M.; Lin, C.-H.; Ong, E.-T.; Lee, C.-F.; Tsai, C.-T.; Lai, L.-P. Elevated Expression of Connective Tissue Growth Factor in Human Atrial Fibrillation and Angiotensin II-Treated Cardiomyocytes. Circ. J. 2011, 75, 1592-1600. [CrossRef]

63. Moreira, L.M.; Takawale, A.; Hulsurkar, M.; Menassa, D.A.; Antanaviciute, A.; Lahiri, S.K.; Mehta, N.; Evans, N.; Psarros, C.; Robinson, P.; et al. Paracrine signalling by cardiac calcitonin controls atrial fibrogenesis and arrhythmia. Nature 2020, 587, 460-465. [CrossRef]

64. Jakob, D.; Klesen, A.; Darkow, E.; Kari, F.A.; Beyersdorf, F.; Kohl, P.; Ravens, U.; Peyronnet, R. Heterogeneity and Remodeling of Ion Currents in Cultured Right Atrial Fibroblasts From Patients With Sinus Rhythm or Atrial Fibrillation. Front. Physiol. 2021, 12. [CrossRef] [PubMed]

65. Ashihara, T.; Haraguchi, R.; Nakazawa, K.; Namba, T.; Ikeda, T.; Nakazawa, Y.; Ozawa, T.; Ito, M.; Horie, M.; Trayanova, N.A. The Role of Fibroblasts in Complex Fractionated Electrograms During Persistent/Permanent Atrial Fibrillation. Circ. Res. 2012, 110, 275-284. [CrossRef] [PubMed]

66. Sánchez, J.; Gomez, J.F.; Martinez-Mateu, L.; Romero, L.; Saiz, J.; Trenor, B. Heterogeneous Effects of Fibroblast-Myocyte Coupling in Different Regions of the Human Atria Under Conditions of Atrial Fibrillation. Front. Physiol. 2019, 10, 847. [CrossRef] 
67. Nagashima, K.; Okumura, Y.; Watanabe, I.; Nakai, T.; Ohkubo, K.; Kofune, M.; Mano, H.; Sonoda, K.; Hiro, T.; Nikaido, M.; et al. Does Location of Epicardial Adipose Tissue Correspond to Endocardial High Dominant Frequency or Complex Fractionated Atrial Electrogram Sites During Atrial Fibrillation? Circ. Arrhythmia Electrophysiol. 2012, 5, 676-683. [CrossRef]

68. Zghaib, T.; Ipek, E.G.; Zahid, S.; Balouch, M.A.; Misra, S.; Ashikaga, H.; Berger, R.D.; Marine, J.E.; Spragg, D.D.; Zimmerman, S.L.; et al. Association of left atrial epicardial adipose tissue with electrogram bipolar voltage and fractionation: Electrophysiologic substrates for atrial fibrillation. Heart Rhythm 2016, 13, 2333-2339. [CrossRef] [PubMed]

69. Mahajan, R.; Nelson, A.; Pathak, R.K.; Middeldorp, M.E.; Wong, C.X.; Twomey, D.J.; Carbone, A.; Teo, K.; Agbaedeng, T.; Linz, D.; et al. Electroanatomical Remodeling of the Atria in Obesity. JACC Clin. Electrophysiol. 2018, 4, 1529-1540. [CrossRef] [PubMed]

70. Nalliah, C.J.; Bell, J.R.; Raaijmakers, A.J.A.; Waddell, H.M.; Wells, S.P.; Bernasochi, G.B.; Montgomery, M.K.; Binny, S.; Watts, T.; Joshi, S.B.; et al. Epicardial Adipose Tissue Accumulation Confers Atrial Conduction Abnormality. J. Am. Coll. Cardiol. 2020, 76, 1197-1211. [CrossRef] [PubMed]

71. Shaihov-Teper, O.; Ram, E.; Ballan, N.; Brzezinski, R.Y.; Naftali-Shani, N.; Masoud, R.; Ziv, T.; Lewis, N.; Schary, Y.; Levin-Kotler, L.-P.; et al. Extracellular Vesicles From Epicardial Fat Facilitate Atrial Fibrillation. Circulation 2021, 143, $2475-2493$. [CrossRef]

72. Suffee, N.; Moore-Morris, T.; Farahmand, P.; Rücker-Martin, C.; Dilanian, G.; Fradet, M.; Sawaki, D.; Derumeaux, G.; LePrince, P.; Clément, K.; et al. Atrial natriuretic peptide regulates adipose tissue accumulation in adult atria. Proc. Natl. Acad. Sci. USA 2017, 114, E771-E780. [CrossRef]

73. Liu, Q.; Zhang, F.; Yang, M.; Zhong, J. Increasing Level of Interleukin-1ß in Epicardial Adipose Tissue Is Associated with Persistent Atrial Fibrillation. J. Interf. Cytokine Res. 2020, 40, 64-69. [CrossRef]

74. Couselo-Seijas, M.; Lopez-Canoa, J.N.; Fernandez, Á.L.; González-Melchor, L.; Seoane, L.M.; Duran-Muñoz, D.; Rozados-Luis, A.; González-Juanatey, J.R.; Rodríguez-Mañero, M.; Eiras, S. Inflammatory and lipid regulation by cholinergic activity in epicardial stromal cells from patients who underwent open-heart surgery. J. Cell. Mol. Med. 2020, 24, 10958-10969. [CrossRef]

75. Kusayama, T.; Furusho, H.; Kashiwagi, H.; Kato, T.; Murai, H.; Usui, S.; Kaneko, S.; Takamura, M. Inflammation of left atrial epicardial adipose tissue is associated with paroxysmal atrial fibrillation. J. Cardiol. 2016, 68, 406-411. [CrossRef]

76. Haemers, P.; Hamdi, H.; Guedj, K.; Suffee, N.; Farahmand, P.; Popovic, N.; Claus, P.; LePrince, P.; Nicoletti, A.; Jalife, J.; et al. Atrial fibrillation is associated with the fibrotic remodelling of adipose tissue in the subepicardium of human and sheep atria. Eur. Heart J. 2017, 38, 53-61. [CrossRef]

77. Kira, S.; Abe, I.; Ishii, Y.; Miyoshi, M.; Oniki, T.; Arakane, M.; Daa, T.; Teshima, Y.; Yufu, K.; Shimada, T.; et al. Role of angiopoietinlike protein 2 in atrial fibrosis induced by human epicardial adipose tissue: Analysis using an organo-culture system. Heart Rhythm 2020, 17, 1591-1601. [CrossRef] [PubMed]

78. Chen, Y.; Liu, F.; Han, F.; Lv, L.; Tang, C.; Xie, Z.; Luo, F. Omentin-1 is associated with atrial fibrillation in patients with cardiac valve disease. BMC Cardiovasc. Disord. 2020, 20, 214. [CrossRef] [PubMed]

79. Venteclef, N.; Guglielmi, V.; Balse, E.; Gaborit, B.; Cotillard, A.; Atassi, F.; Amour, J.; Leprince, P.; Dutour, A.; Clément, K.; et al. Human epicardial adipose tissue induces fibrosis of the atrial myocardium through the secretion of adipo-fibrokines. Eur. Heart J. 2015, 36, 795-805. [CrossRef] [PubMed]

80. Wang, Q.; Shen, H.; Min, J.; Gao, Y.; Liu, K.; Xi, W.; Yang, J.; Yin, L.; Xu, J.; Xiao, J.; et al. YKL-40 is highly expressed in the epicardial adipose tissue of patients with atrial fibrillation and associated with atrial fibrosis. J. Transl. Med. 2018, 16, 229. [CrossRef]

81. Aksu, T.; Yalin, K.; Bozyel, S.; Gopinathannair, R.; Gupta, D. The anatomical basis behind the neuromodulation effects associated with pulmonary vein isolation. J. Cardiovasc. Electrophysiol. 2021, 32, 1733-1736. [CrossRef]

82. Pachon, J.C.; Pachon, E.I.; Pachon, C.T.C.; Santillana, T.G.; Lobo, T.J.; Pachon, J.C.; Zerpa, J.C.; Cunha, M.Z.; Higuti, C.; Ortencio, F.A.; et al. Long-Term Evaluation of the Vagal Denervation by Cardioneuroablation Using Holter and Heart Rate Variability. Circ. Arrhythmia Electrophysiol. 2020, 13, e008703. [CrossRef]

83. Zhu, Z.; Wang, W.; Cheng, Y.; Wang, X.; Sun, J. The predictive value of heart rate variability indices tested in early period after radiofrequency catheter ablation for the recurrence of atrial fibrillation. J. Cardiovasc. Electrophysiol. 2020, 31, 1350-1355. [CrossRef]

84. Kusayama, T.; Douglas, A.; Wan, J.; Doytchinova, A.; Wong, J.; Mitscher, G.; Straka, S.; Shen, C.; Everett, T.H.; Chen, P.-S. Skin sympathetic nerve activity and ventricular rate control during atrial fibrillation. Heart Rhythm 2020, 17, 544-552. [CrossRef]

85. Kawasaki, M.; Yamada, T.; Furukawa, Y.; Morita, T.; Tamaki, S.; Kida, H.; Sakata, Y.; Fukunami, M. Are cardiac sympathetic nerve activity and epicardial adipose tissue associated with atrial fibrillation recurrence after catheter ablation in patients without heart failure? Int. J. Cardiol. 2020, 303, 41-48. [CrossRef]

86. Kampaktsis, P.N.; Oikonomou, E.K.; Choi, D.Y.; Cheung, J.W. Efficacy of ganglionated plexi ablation in addition to pulmonary vein isolation for paroxysmal versus persistent atrial fibrillation: A meta-analysis of randomized controlled clinical trials. J. Interv. Card. Electrophysiol. 2017, 50, 253-260. [CrossRef]

87. Waldron, N.H.; Cooter, M.; Haney, J.C.; Schroder, J.N.; Gaca, J.G.; Lin, S.S.; Sigurdsson, M.I.; Fudim, M.; Podgoreanu, M.V.; Stafford-Smith, M.; et al. Temporary autonomic modulation with botulinum toxin type A to reduce atrial fibrillation after cardiac surgery. Heart Rhythm 2019, 16, 178-184. [CrossRef] 
88. Romanov, A.; Pokushalov, E.; Ponomarev, D.; Bayramova, S.; Shabanov, V.; Losik, D.; Stenin, I.; Elesin, D.; Mikheenko, I.; Strelnikov, A.; et al. Long-term suppression of atrial fibrillation by botulinum toxin injection into epicardial fat pads in patients undergoing cardiac surgery: Three-year follow-up of a randomized study. Heart Rhythm 2019, 16, 172-177. [CrossRef] [PubMed]

89. Wang, H.; Zhang, Y.; Xin, F.; Jiang, H.; Tao, D.; Jin, Y.; He, Y.; Wang, Q.; Po, S.S. Calcium-Induced Autonomic Denervation in Patients with Post-Operative Atrial Fibrillation. J. Am. Coll. Cardiol. 2021, 77, 57-67. [CrossRef]

90. Stavrakis, S.; Stoner, J.A.; Humphrey, M.B.; Morris, L.; Filiberti, A.; Reynolds, J.C.; Elkholey, K.; Javed, I.; Twidale, N.; Riha, P.; et al. TREAT AF (Transcutaneous Electrical Vagus Nerve Stimulation to Suppress Atrial Fibrillation). JACC Clin. Electrophysiol. 2020, 6, 282-291. [CrossRef]

91. Wu, J.; Deng, H.; Chen, Q.; Wu, Q.; Li, X.; Jiang, S.; Wang, F.; Ye, F.; Ou, L.; Gao, H. Comprehensive Analysis of Differential Immunocyte Infiltration and Potential ceRNA Networks Involved in the Development of Atrial Fibrillation. BioMed Res. Int. 2020, 2020, 8021208. [CrossRef]

92. Hohmann, C.; Pfister, R.; Mollenhauer, M.; Adler, C.; Kozlowski, J.; Wodarz, A.; Drebber, U.; Wippermann, J.; Michels, G. Inflammatory cell infiltration in left atrial appendageal tissues of patients with atrial fibrillation and sinus rhythm. Sci. Rep. 2020, 10, 1685. [CrossRef]

93. Yamashita, T.; Sekiguchi, A.; Iwasaki, Y.; Date, T.; Sagara, K.; Tanabe, H.; Suma, H.; Sawada, H.; Aizawa, T. Recruitment of Immune Cells Across Atrial Endocardium in Human Atrial Fibrillation. Circ. J. 2010, 74, 262-270. [CrossRef]

94. Smorodinova, N.; Bláha, M.; Melenovský, V.; Rozsívalová, K.; Přidal, J.; Ďurišová, M.; Pirk, J.; Kautzner, J.; Kučera, T. Analysis of immune cell populations in atrial myocardium of patients with atrial fibrillation or sinus rhythm. PLoS ONE 2017, 12, e0172691. [CrossRef]

95. Chen, Y.; Chang, G.; Chen, X.; Li, Y.; Li, H.; Cheng, D.; Tang, Y.; Sang, H. IL-6-miR-210 Suppresses Regulatory T Cell Function and Promotes Atrial Fibrosis by Targeting Foxp3. Mol. Cells 2020, 43, 438-447. [CrossRef] [PubMed]

96. Rao, F.; Deng, C.-Y.; Wu, S.-L.; Xiao, D.-Z.; Yu, X.-Y.; Kuang, S.-J.; Lin, Q.-X.; Shan, Z.-X. Involvement of Src in L-type Ca ${ }^{2+}$ channel depression induced by macrophage migration inhibitory factor in atrial myocytes. J. Mol. Cell. Cardiol. 2009, 47, 586-594. [CrossRef] [PubMed]

97. Ambale-Venkatesh, B.; Yang, X.; Wu, C.O.; Liu, K.; Hundley, W.G.; McClelland, R.; Gomes, A.S.; Folsom, A.R.; Shea, S.; Guallar, E.; et al. Cardiovascular Event Prediction by Machine Learning. Circ. Res. 2017, 121, 1092-1101. [CrossRef] [PubMed]

98. Pan, J.; Wang, W.; Wu, X.; Kong, F.; Pan, J.; Lin, J.; Zhang, M. Inflammatory cytokines in cardiac pacing patients with atrial fibrillation and asymptomatic atrial fibrillation. Panminerva Med. 2018, 60, 86-91. [CrossRef] [PubMed]

99. Maida, C.D.; Vasto, S.; Di Raimondo, D.; Casuccio, A.; Vassallo, V.; Daidone, M.; Del Cuore, A.; Pacinella, G.; Cirrincione, A.; Simonetta, I.; et al. Inflammatory activation and endothelial dysfunction markers in patients with permanent atrial fibrillation: A cross-sectional study. Aging 2020, 12, 8423-8433. [CrossRef]

100. De Gennaro, L.; Brunetti, N.D.; Montrone, D.; De Rosa, F.; Cuculo, A.; Di Biase, M. Inflammatory activation and carbohydrate antigen-125 levels in subjects with atrial fibrillation. Eur. J. Clin. Investig. 2012, 42, 371-375. [CrossRef] [PubMed]

101. Liuba, I.; Ahlmroth, H.; Jonasson, L.; Englund, A.; Jonsson, A.; Safstrom, K.; Walfridsson, H. Source of inflammatory markers in patients with atrial fibrillation. Europace 2008, 10, 848-853. [CrossRef]

102. Lin, Y.-J.; Tsao, H.-M.; Chang, S.-L.; Lo, L.-W.; Tuan, T.-C.; Hu, Y.-F.; Udyavar, A.R.; Tsai, W.-C.; Chang, C.-J.; Tai, C.-T.; et al. Prognostic Implications of the High-Sensitive C-Reactive Protein in the Catheter Ablation of Atrial Fibrillation. Am. J. Cardiol. 2010, 105, 495-501. [CrossRef]

103. Yao, C.; Veleva, T.; Scott, L.; Cao, S.; Li, L.; Chen, G.; Jeyabal, P.; Pan, X.; Alsina, K.M.; Abu-Taha, I.; et al. Enhanced Cardiomyocyte NLRP3 Inflammasome Signaling Promotes Atrial Fibrillation. Circulation 2018, 138, 2227-2242. [CrossRef] [PubMed]

104. Heijman, J.; Muna, A.P.; Veleva, T.; Molina, C.E.; Sutanto, H.; Tekook, M.; Wang, Q.; Abu-Taha, I.H.; Gorka, M.; Künzel, S.; et al Atrial myocyte NLRP3/CaMKII nexus forms a substrate for postoperative atrial fibrillation. Circ. Res. 2020, 127, 1036-1055. [CrossRef] [PubMed]

105. Liu, C.; Wang, J.; Yiu, D.; Liu, K. The Efficacy of Glucocorticoids for the Prevention of Atrial Fibrillation, or Length of Intensive Care Unite or Hospital Stay After Cardiac Surgery: A Meta-Analysis. Cardiovasc. Ther. 2014, 32, 89-96. [CrossRef] [PubMed]

106. Liu, L.; Jing, F.-Y.; Wang, X.-W.; Li, L.-J.; Zhou, R.-Q.; Zhang, C.; Wu, Q.-C. Effects of corticosteroids on new-onset atrial fibrillation after cardiac surgery. Medicine 2021, 100, e25130. [CrossRef]

107. Papageorgiou, N.; Briasoulis, A.; Lazaros, G.; Imazio, M.; Tousoulis, D. Colchicine for prevention and treatment of cardiac diseases: A meta-analysis. Cardiovasc. Ther. 2017, 35, 10-18. [CrossRef]

108. Deftereos, S.G.; Vrachatis, D.A.; Angelidis, C.; Vrettou, A.-R.; Sarri, E.K.; Giotaki, S.G.; Varytimiadi, E.; Kossyvakis, C.; Kotsia, E.; Deftereos, G.S.; et al. The Role of Colchicine in Treating Postoperative and Post-catheter Ablation Atrial Fibrillation. Clin. Ther. 2019, 41, 21-29. [CrossRef]

109. Sabath, N.; Levy-Adam, F.; Younis, A.; Rozales, K.; Meller, A.; Hadar, S.; Soueid-Baumgarten, S.; Shalgi, R. Cellular proteostasis decline in human senescence. Proc. Natl. Acad. Sci. USA 2020, 117, 31902-31913. [CrossRef]

110. Arrieta, A.; Blackwood, E.A.; Stauffer, W.T.; Glembotski, C.C. Integrating ER and Mitochondrial Proteostasis in the Healthy and Diseased Heart. Front. Cardiovasc. Med. 2020, 6, 193. [CrossRef]

111. Brundel, B.J.J.M.; Henning, R.H.; Ke, L.; van Gelder, I.C.; Crijns, H.J.G.M.; Kampinga, H.H. Heat shock protein upregulation protects against pacing-induced myolysis in HL-1 atrial myocytes and in human atrial fibrillation. J. Mol. Cell. Cardiol. 2006, 41, 555-562. [CrossRef] 
112. Hu, Y.-F.; Yeh, H.-I.; Tsao, H.-M.; Tai, C.-T.; Lin, Y.-J.; Chang, S.-L.; Lo, L.-W.; Tuan, T.-C.; Suenari, K.; Li, C.-H.; et al. Electrophysiological Correlation and Prognostic Impact of Heat Shock Protein 27 in Atrial Fibrillation. Circ. Arrhythmia Electrophysiol. 2012, 5, 334-340. [CrossRef] [PubMed]

113. Marion, D.; Lanters, E.A.; Ramos, K.S.; Li, J.; Wiersma, M.; Baks-te Bulte, L.; JQMMuskens, A.; Boersma, E.; de Groot, N.; Brundel, B.J. Evaluating Serum Heat Shock Protein Levels as Novel Biomarkers for Atrial Fibrillation. Cells 2020, 9, 2105. [CrossRef] [PubMed]

114. Wiersma, M.; Meijering, R.A.M.; Qi, X.; Zhang, D.; Liu, T.; Hoogstra-Berends, F.; Sibon, O.C.M.; Henning, R.H.; Nattel, S.; Brundel, B.J.J.M. Endoplasmic Reticulum Stress Is Associated with Autophagy and Cardiomyocyte Remodeling in Experimental and Human Atrial Fibrillation. J. Am. Heart Assoc. 2017, 6, e006458. [CrossRef] [PubMed]

115. Brundel, B. Activation of proteolysis by calpains and structural changes in human paroxysmal and persistent atrial fibrillation. Cardiovasc. Res. 2002, 54, 380-389. [CrossRef]

116. Zhang, D.; Wu, C.-T.; Qi, X.; Meijering, R.A.M.; Hoogstra-Berends, F.; Tadevosyan, A.; Cubukcuoglu Deniz, G.; Durdu, S.; Akar, A.R.; Sibon, O.C.M.; et al. Activation of Histone Deacetylase-6 Induces Contractile Dysfunction Through Derailment of $\alpha$-Tubulin Proteostasis in Experimental and Human Atrial Fibrillation. Circulation 2014, 129, 346-358. [CrossRef]

117. Sawa, Y.; Matsushita, N.; Sato, S.; Ishida, N.; Saito, M.; Sanbe, A.; Morino, Y.; Taira, E.; Obara, M.; Hirose, M. Chronic HDAC6 Activation Induces Atrial Fibrillation Through Atrial Electrical and Structural Remodeling in Transgenic Mice. Int. Heart J. 2021, 62, 616-626. [CrossRef]

118. Zhang, D.; Hu, X.; Li, J.; Liu, J.; Baks-te Bulte, L.; Wiersma, M.; Malik, N.-A.; van Marion, D.M.S.; Tolouee, M.; Hoogstra-Berends, F; et al. DNA damage-induced PARP1 activation confers cardiomyocyte dysfunction through NAD ${ }^{+}$ depletion in experimental atrial fibrillation. Nat. Commun. 2019, 10, 1307. [CrossRef]

119. Kim, Y.M.; Guzik, T.J.; Zhang, Y.H.; Zhang, M.H.; Kattach, H.; Ratnatunga, C.; Pillai, R.; Channon, K.M.; Casadei, B. A myocardial Nox2 containing NAD(P)H oxidase contributes to oxidative stress in human atrial fibrillation. Circ. Res. 2005, 97, 629-636. [CrossRef]

120. Liu, T.; Shao, Q.; Korantzopoulos, P.; Liu, E.; Xu, G.; Li, G. Serum levels of nicotinamide-adenine dinucleotide phosphate oxidase 4 are associated with non-valvular atrial fibrillation. Biomed. Rep. 2015, 3, 864-868. [CrossRef]

121. Li, J.; Zhang, D.; Ramos, K.S.; Baks, L.; Wiersma, M.; Lanters, E.A.H.; Bogers, A.J.J.C.; de Groot, N.M.S.; Brundel, B.J.J.M. Blood-based 8-hydroxy-2'-deoxyguanosine level: A potential diagnostic biomarker for atrial fibrillation. Heart Rhythm 2021, 18, 271-277. [CrossRef] [PubMed]

122. Toyama, K.; Yamabe, H.; Uemura, T.; Nagayoshi, Y.; Morihisa, K.; Koyama, J.; Kanazawa, H.; Hoshiyama, T.; Ogawa, H. Analysis of oxidative stress expressed by urinary level of 8-hydroxy-2'-deoxyguanosine and biopyrrin in atrial fibrillation: Effect of sinus rhythm restoration. Int. J. Cardiol. 2013, 168, 80-85. [CrossRef] [PubMed]

123. Wiersma, M.; van Marion, D.; Wüst, R.C.; Houtkooper, R.H.; Zhang, D.; de Groot, N.; Henning, R.H.; Brundel, B.J. Mitochondrial Dysfunction Underlies Cardiomyocyte Remodeling in Experimental and Clinical Atrial Fibrillation. Cells 2019, 8, 1202. [CrossRef] [PubMed]

124. Emelyanova, L.; Ashary, Z.; Cosic, M.; Negmadjanov, U.; Ross, G.; Rizvi, F.; Olet, S.; Kress, D.; Sra, J.; Tajik, A.J.; et al. Selective downregulation of mitochondrial electron transport chain activity and increased oxidative stress in human atrial fibrillation. Am. J. Physiol. Circ. Physiol. 2016, 311, H54-H63. [CrossRef] [PubMed]

125. Montaigne, D.; Marechal, X.; Lefebvre, P.; Modine, T.; Fayad, G.; Dehondt, H.; Hurt, C.; Coisne, A.; Koussa, M.; Remy-Jouet, I.; et al. Mitochondrial Dysfunction as an Arrhythmogenic Substrate. J. Am. Coll. Cardiol. 2013, 62, 14661473. [CrossRef]

126. Chen, G.; Guo, H.; Song, Y.; Chang, H.; Wang, S.; Zhang, M.; Liu, C. Long non-coding RNA AK055347 is upregulated in patients with atrial fibrillation and regulates mitochondrial energy production in myocardiocytes. Mol. Med. Rep. 2016, 14, 5311-5317. [CrossRef]

127. Xie, W.; Santulli, G.; Reiken, S.R.; Yuan, Q.; Osborne, B.W.; Chen, B.-X.; Marks, A.R. Mitochondrial oxidative stress promotes atrial fibrillation. Sci. Rep. 2015, 5, 11427. [CrossRef] [PubMed]

128. Harada, M.; Tadevosyan, A.; Qi, X.; Xiao, J.; Liu, T.; Voigt, N.; Karck, M.; Kamler, M.; Kodama, I.; Murohara, T.; et al. Atrial Fibrillation Activates AMP-Dependent Protein Kinase and its Regulation of Cellular Calcium Handling. J. Am. Coll. Cardiol. 2015, 66, 47-58. [CrossRef]

129. Gharaviri, A.; Pezzuto, S.; Potse, M.; Conte, G.; Zeemering, S.; Sobota, V.; Verheule, S.; Krause, R.; Auricchio, A.; Schotten, U. Synergistic antiarrhythmic effect of inward rectifier current inhibition and pulmonary vein isolation in a 3D computer model for atrial fibrillation. EP Eur. 2021, 23, i161-i168. [CrossRef]

130. Abramochkin, D.V.; Kuzmin, V.S.; Rosenshtraukh, L.V. A New Class III Antiarrhythmic Drug Niferidil Prolongs Action Potentials in Guinea Pig Atrial Myocardium via Inhibition of Rapid Delayed Rectifier. Cardiovasc. Drugs Ther. 2017, 31, 525-533. [CrossRef]

131. Takemoto, Y.; Slough, D.P.; Meinke, G.; Katnik, C.; Graziano, Z.A.; Chidipi, B.; Reiser, M.; Alhadidy, M.M.; Ramirez, R.; SalvadorMontañés, O.; et al. Structural basis for the antiarrhythmic blockade of a potassium channel with a small molecule. FASEB J. 2018, 32, 1778-1793. [CrossRef] [PubMed]

132. Fenner, M.F.; Carstensen, H.; Dalgas Nissen, S.; Melis Hesselkilde, E.; Scott Lunddahl, C.; Adler Hess Jensen, M.; Loft-Andersen, A.V.; Sattler, S.M.; Platonov, P.; El-Haou, S.; et al. Effect of selective $I_{\mathrm{K}, \mathrm{ACh}}$ inhibition by XAF-1407 in an equine model of tachypacing-induced persistent atrial fibrillation. Br. J. Pharmacol. 2020, 177, 3778-3794. [CrossRef] 
133. Sobota, V.; Gatta, G.; van Hunnik, A.; van Tuijn, I.; Kuiper, M.; Milnes, J.; Jespersen, T.; Schotten, U.; Verheule, S. The AcetylcholineActivated Potassium Current Inhibitor XAF-1407 Terminates Persistent Atrial Fibrillation in Goats. Front. Pharmacol. 2020, 11, 608410. [CrossRef]

134. Ji, Y.; Varkevisser, R.; Opacic, D.; Bossu, A.; Kuiper, M.; Beekman, J.D.M.; Yang, S.; Khan, A.P.; Dobrev, D.; Voigt, N.; et al. The inward rectifier current inhibitor PA-6 terminates atrial fibrillation and does not cause ventricular arrhythmias in goat and dog models. Br. J. Pharmacol. 2017, 174, 2576-2590. [CrossRef]

135. Schmidt, C.; Wiedmann, F.; Beyersdorf, C.; Zhao, Z.; El-Battrawy, I.; Lan, H.; Szabo, G.; Li, X.; Lang, S.; Korkmaz-Icöz, S.; et al. Genetic Ablation of TASK-1 (Tandem of P Domains in a Weak Inward Rectifying $\mathrm{K}^{+}$Channel-Related Acid-Sensitive $\mathrm{K}^{+}$Channel1) $\left(\mathrm{K}_{2 \mathrm{P}} 3.1\right) \mathrm{K}^{+}$Channels Suppresses Atrial Fibrillation and Prevents Electrical Remodeling. Circ. Arrhythmia Electrophysiol. 2019, 12, e007465. [CrossRef] [PubMed]

136. Wiedmann, F.; Beyersdorf, C.; Zhou, X.; Büscher, A.; Kraft, M.; Nietfeld, J.; Walz, T.P.; Unger, L.A.; Loewe, A.; Schmack, B.; et al. Pharmacologic TWIK-Related Acid-Sensitive K+ Channel (TASK-1) Potassium Channel Inhibitor A293 Facilitates Acute Cardioversion of Paroxysmal Atrial Fibrillation in a Porcine Large Animal Model. J. Am. Heart Assoc. 2020, 9, e015751. [CrossRef]

137. Wiedmann, F.; Beyersdorf, C.; Zhou, X.-B.; Kraft, M.; Paasche, A.; Jávorszky, N.; Rinné, S.; Sutanto, H.; Büscher, A.; Foerster, K.I.; et al. Treatment of atrial fibrillation with doxapram: TASK-1 potassium channel inhibition as a novel pharmacological strategy. Cardiovasc. Res. 2021. [CrossRef]

138. Walfridsson, H.; Anfinsen, O.-G.; Berggren, A.; Frison, L.; Jensen, S.; Linhardt, G.; Nordkam, A.-C.; Sundqvist, M.; Carlsson, L. Is the acetylcholine-regulated inwardly rectifying potassium current a viable antiarrhythmic target? Translational discrepancies of AZD2927 and A7071 in dogs and humans. EP Eur. 2015, 17, 473-482. [CrossRef]

139. Ford, J.; Milnes, J.; El Haou, S.; Wettwer, E.; Loose, S.; Matschke, K.; Tyl, B.; Round, P.; Ravens, U. The positive frequencydependent electrophysiological effects of the IKur inhibitor XEN-D0103 are desirable for the treatment of atrial fibrillation. Heart Rhythm 2016, 13, 555-564. [CrossRef] [PubMed]

140. Shunmugam, S.R.; Sugihara, C.; Freemantle, N.; Round, P.; Furniss, S.; Sulke, N. A double-blind, randomised, placebo-controlled, cross-over study assessing the use of XEN-D0103 in patients with paroxysmal atrial fibrillation and implanted pacemakers allowing continuous beat-to-beat monitoring of drug efficacy. J. Interv. Card. Electrophysiol. 2018, 51, 191-197. [CrossRef] [PubMed]

141. Kikuchi, K.; McDonald, A.D.; Sasano, T.; Donahue, J.K. Targeted Modification of Atrial Electrophysiology by Homogeneous Transmural Atrial Gene Transfer. Circulation 2005, 111, 264-270. [CrossRef]

142. Amit, G.; Kikuchi, K.; Greener, I.D.; Yang, L.; Novack, V.; Donahue, J.K. Selective Molecular Potassium Channel Blockade Prevents Atrial Fibrillation. Circulation 2010, 121, 2263-2270. [CrossRef] [PubMed]

143. Soucek, R.; Thomas, D.; Kelemen, K.; Bikou, O.; Seyler, C.; Voss, F.; Becker, R.; Koenen, M.; Katus, H.A.; Bauer, A. Genetic suppression of atrial fibrillation using a dominant-negative ether-a-go-go-related gene mutant. Heart Rhythm 2012, 9, 265-272. [CrossRef] [PubMed]

144. Liu, Z.; Hutt, J.A.; Rajeshkumar, B.; Azuma, Y.; Duan, K.L.; Donahue, J.K. Preclinical efficacy and safety of KCNH2-G628S gene therapy for postoperative atrial fibrillation. J. Thorac. Cardiovasc. Surg. 2017, 154, 1644-1651.e8. [CrossRef] [PubMed]

145. Bikou, O.; Thomas, D.; Trappe, K.; Lugenbiel, P.; Kelemen, K.; Koch, M.; Soucek, R.; Voss, F.; Becker, R.; Katus, H.A.; et al. Connexin 43 gene therapy prevents persistent atrial fibrillation in a porcine model. Cardiovasc. Res. 2011, 92, 218-225. [CrossRef]

146. Igarashi, T.; Finet, J.E.; Takeuchi, A.; Fujino, Y.; Strom, M.; Greener, I.D.; Rosenbaum, D.S.; Donahue, J.K. Connexin Gene Transfer Preserves Conduction Velocity and Prevents Atrial Fibrillation. Circulation 2012, 125, 216-225. [CrossRef]

147. Zhou, T.; Han, Z.; Gu, J.; Chen, S.; Fan, Y.; Zhang, H.; Yin, Y.; Zhang, J.; Wang, C. Angiotensin-converting enzyme-2 overexpression improves atrial electrical remodeling through TRPM7 signaling pathway. Oncotarget 2017, 8, 78726-78733. [CrossRef]

148. Dittrich, H.C.; Feld, G.K.; Bahnson, T.D.; Camm, A.J.; Golitsyn, S.; Katz, A.; Koontz, J.I.; Kowey, P.R.; Waldo, A.L.; Brown, A.M. COR-ART: A multicenter, randomized, double-blind, placebo-controlled dose-ranging study to evaluate single oral doses of vanoxerine for conversion of recent-onset atrial fibrillation or flutter to normal sinus rhythm. Heart Rhythm 2015, 12, 1105-1112. [CrossRef]

149. Piccini, J.P.; Pritchett, E.L.C.; Davison, B.A.; Cotter, G.; Wiener, L.E.; Koch, G.; Feld, G.; Waldo, A.; van Gelder, I.C.; Camm, A.J.; et al. Randomized, double-blind, placebo-controlled study to evaluate the safety and efficacy of a single oral dose of vanoxerine for the conversion of subjects with recent onset atrial fibrillation or flutter to normal sinus rhythm: RESTORE SR. Heart Rhythm 2016, 13, 1777-1783. [CrossRef]

150. Hagiwara-Nagasawa, M.; Kambayashi, R.; Goto, A.; Nunoi, Y.; Izumi-Nakaseko, H.; Takei, Y.; Matsumoto, A.; Sugiyama, A. Cardiohemodynamic and Arrhythmogenic Effects of the Anti-Atrial Fibrillatory Compound Vanoxerine in HalothaneAnesthetized Dogs. Cardiovasc. Toxicol. 2021, 21, 206-215. [CrossRef]

151. Farkowski, M.M.; Maciag, A.; Kowalik, I.; Konka, M.; Szwed, H.; Pytkowski, M. Intravenous antazoline, a first-generation antihistaminic drug with antiarrhythmic properties, is a suitable agent for pharmacological cardioversion of atrial fibrillation induced during pulmonary vein isolation due to the lack of influence on atrio-venou. Br. J. Clin. Pharmacol. 2019, 85, 1552-1558. [CrossRef]

152. Balsam, P.; Koźluk, E.; Peller, M.; Piątkowska, A.; Lodziński, P.; Kiliszek, M.; Kołtowski, Ł.; Grabowski, M.; Opolski, G. Antazoline for termination of atrial fibrillation during the procedure of pulmonary veins isolation. Adv. Med. Sci. 2015, 60, 231-235. [CrossRef] 
153. Maciag, A.; Farkowski, M.M.; Chwyczko, T.; Beckowski, M.; Syska, P.; Kowalik, I.; Pytkowski, M.; Wozniak, J.; Dabrowski, R.; Szwed, H. Efficacy and safety of antazoline in the rapid cardioversion of paroxysmal atrial fibrillation (the AnPAF Study). EP Eur. 2017, 19, 1637-1642. [CrossRef]

154. Farkowski, M.M.; Maciag, A.; Zurawska, M.; Kowalik, I.; Szwed, H.; Pytkowski, M. Clinical effectiveness and safety of antazolinebased therapy in patients with stable coronary artery disease undergoing pharmacological cardioversion of short-duration atrial fibrillation in the emergency department. Cardiovasc. Ther. 2018, 36, e12469. [CrossRef]

155. Wybraniec, M.T.; Wróbel, W.; Wilkosz, K.; Wrona, K.; Bula, K.; Mizia-Stec, K. Pharmacological Cardioversion with Antazoline in Atrial Fibrillation: The Results of the CANT Study. J. Am. Heart Assoc. 2018, 7, e010153. [CrossRef] [PubMed]

156. deSouza, I.S.; Tadrous, M.; Sexton, T.; Benabbas, R.; Carmelli, G.; Sinert, R. Pharmacologic Cardioversion of Recent-Onset Atrial Fibrillation and Flutter in the Emergency Department: A Systematic Review and Network Meta-analysis. Ann. Emerg. Med. 2020, 76, 14-30. [CrossRef] [PubMed]

157. Verrier, R.L.; Bonatti, R.; Silva, A.F.G.; Batatinha, J.A.P.; Nearing, B.D.; Liu, G.; Rajamani, S.; Zeng, D.; Belardinelli, L. If inhibition in the atrioventricular node by ivabradine causes rate-dependent slowing of conduction and reduces ventricular rate during atrial fibrillation. Heart Rhythm 2014, 11, 2288-2296. [CrossRef]

158. Caminiti, G.; Fossati, C.; Rosano, G.; Volterrani, M. Addition of ivabradine to betablockers in patients with atrial fibrillation: Effects on heart rate and exercise tolerance. Int. J. Cardiol. 2016, 202, 73-74. [CrossRef] [PubMed]

159. Wongcharoen, W.; Ruttanaphol, A.; Gunaparn, S.; Phrommintikul, A. Ivabradine reduced ventricular rate in patients with non-paroxysmal atrial fibrillation. Int. J. Cardiol. 2016, 224, 252-255. [CrossRef]

160. Fontenla, A.; López-Gil, M.; Tamargo-Menéndez, J.; Matía-Francés, R.; Salgado-Aranda, R.; Rey-Blas, J.R.; Miracle-Blanco, Á.; Mejía-Martínez, E.; Pastor-Fuentes, A.; Toquero-Ramos, J.; et al. Ivabradine for chronic heart rate control in persistent atrial fibrillation. Design of the BRAKE-AF project. Rev. Esp. Cardiol. (Engl. Ed.) 2020, 73, 368-375. [CrossRef]

161. Mengesha, H.G.; Weldearegawi, B.; Petrucka, P.; Bekele, T.; Otieno, M.G.; Hailu, A. Effect of ivabradine on cardiovascular outcomes in patients with stable angina: Meta-analysis of randomized clinical trials. BMC Cardiovasc. Disord. 2017, 17, 105. [CrossRef]

162. Nofi, C.; Zhang, K.; Tang, Y.-D.; Li, Y.; Migirov, A.; Ojamaa, K.; Gerdes, A.M.; Zhang, Y. Chronic dantrolene treatment attenuates cardiac dysfunction and reduces atrial fibrillation inducibility in a rat myocardial infarction heart failure model. Heart Rhythm O2 2020, 1, 126-135. [CrossRef]

163. Zhang, Y.; Qi, Y.; Li, J.-J.; He, W.-J.; Gao, X.-H.; Zhang, Y.; Sun, X.; Tong, J.; Zhang, J.; Deng, X.-L.; et al. Stretch-induced sarcoplasmic reticulum calcium leak is causatively associated with atrial fibrillation in pressure-overloaded hearts. Cardiovasc. Res. 2021, 117, 1091-1102. [CrossRef]

164. Delfiner, M.S.; Nofi, C.; Li, Y.; Gerdes, A.M.; Zhang, Y. Failing Hearts Are More Vulnerable to Sympathetic, but Not Vagal Stimulation-Induced, Atrial Fibrillation-Ameliorated with Dantrolene Treatment. J. Card. Fail. 2018, 24, 460-469. [CrossRef] [PubMed]

165. Lee, J.S.; Greco, L.; Migirov, A.; Li, Y.; Gerdes, A.M.; Zhang, Y. Chronic Dantrolene Treatment Does Not Affect Hypertension, but Attenuates Sympathetic Stimulation Enhanced Atrial Fibrillation Inducibility in SHR. Am. J. Hypertens. 2020, 33, 407-413. [CrossRef]

166. Liu, T.; Xiong, F.; Qi, X.-Y.; Xiao, J.; Villeneuve, L.; Abu-Taha, I.; Dobrev, D.; Huang, C.; Nattel, S. Altered calcium handling produces reentry-promoting action potential alternans in atrial fibrillation-remodeled hearts. JCI Insight 2020, 5, e133754. [CrossRef] [PubMed]

167. Pabel, S.; Mustroph, J.; Stehle, T.; Lebek, S.; Dybkova, N.; Keyser, A.; Rupprecht, L.; Wagner, S.; Neef, S.; Maier, L.S.; et al. Dantrolene reduces CaMKII C-mediated atrial arrhythmias. EP Eur. 2020, 22, 1111-1118. [CrossRef]

168. Filippatos, G.; Bakris, G.L.; Pitt, B.; Agarwal, R.; Rossing, P.; Ruilope, L.M.; Butler, J.; Lam, C.S.P.; Kolkhof, P.; Roberts, L.; et al. Finerenone Reduces New-Onset Atrial Fibrillation in Patients With Chronic Kidney Disease and Type 2 Diabetes. J. Am. Coll. Cardiol. 2021, 78, 142-152. [CrossRef] [PubMed]

169. Parikh, A.; Patel, D.; McTiernan, C.F.; Xiang, W.; Haney, J.; Yang, L.; Lin, B.; Kaplan, A.D.; Bett, G.C.L.; Rasmusson, R.L.; et al. Relaxin Suppresses Atrial Fibrillation by Reversing Fibrosis and Myocyte Hypertrophy and Increasing Conduction Velocity and Sodium Current in Spontaneously Hypertensive Rat Hearts. Circ. Res. 2013, 113, 313-321. [CrossRef] [PubMed]

170. Henry, B.L.; Gabris, B.; Li, Q.; Martin, B.; Giannini, M.; Parikh, A.; Patel, D.; Haney, J.; Schwartzman, D.S.; Shroff, S.G.; et al. Relaxin suppresses atrial fibrillation in aged rats by reversing fibrosis and upregulating $\mathrm{Na}^{+}$channels. Heart Rhythm 2016, 13, 983-991. [CrossRef] [PubMed]

171. Martin, B.; Gabris, B.; Barakat, A.F.; Henry, B.L.; Giannini, M.; Reddy, R.P.; Wang, X.; Romero, G.; Salama, G. Relaxin reverses maladaptive remodeling of the aged heart through Wnt-signaling. Sci. Rep. 2019, 9, 18545. [CrossRef]

172. Qu, X.; Chen, L.; Sun, L.; Chen, C.; Gao, Z.; Huang, W.; Zhou, H. Serum relaxin level predicts recurrence of atrial fibrillation after radiofrequency catheter ablation. Heart Vessel. 2019, 34, 1543-1551. [CrossRef] [PubMed]

173. Filippatos, G.; Farmakis, D.; Metra, M.; Cotter, G.; Davison, B.A.; Felker, G.M.; Greenberg, B.H.; Hua, T.A.; Pang, P.S.; Ponikowski, P.; et al. Serelaxin in acute heart failure patients with and without atrial fibrillation: A secondary analysis of the RELAX-AHF trial. Clin. Res. Cardiol. 2017, 106, 444-456. [CrossRef] 
174. Ge, Z.; Chen, Y.; Wang, B.; Zhang, X.; Yan, Y.; Zhou, L.; Zhang, Y.; Xie, Y. MFGE8 attenuates Ang-II-induced atrial fibrosis and vulnerability to atrial fibrillation through inhibition of TGF- $\beta 1 / S m a d 2 / 3$ pathway. J. Mol. Cell. Cardiol. 2020, 139, $164-175$. [CrossRef] [PubMed]

175. Ridker, P.M.; Everett, B.M.; Thuren, T.; MacFadyen, J.G.; Chang, W.H.; Ballantyne, C.; Fonseca, F.; Nicolau, J.; Koenig, W.; Anker, S.D.; et al. Antiinflammatory Therapy with Canakinumab for Atherosclerotic Disease. N. Engl. J. Med. 2017, 377, 11191131. [CrossRef]

176. Krisai, P.; Blum, S.; Schnabel, R.B.; Sticherling, C.; Kühne, M.; von Felten, S.; Ammann, P.; Pruvot, E.; Albert, C.M.; Conen, D. Canakinumab After Electrical Cardioversion in Patients With Persistent Atrial Fibrillation. Circ. Arrhythmia Electrophysiol. 2020, 13, e008197. [CrossRef] [PubMed]

177. Vrachatis, D.A.; Papathanasiou, K.A.; Giotaki, S.G.; Iliodromitis, K.E.; Papaioannou, T.G.; Stefanini, G.G.; Cleman, M.; Siasos, G.; Reimers, B.; Lansky, A.; et al. Repurposing colchicine's journey in view of drug-to-drug interactions. A review. Toxicol. Rep. 2021, 8, 1389-1393. [CrossRef] [PubMed]

178. Verma, S.; Eikelboom, J.W.; Nidorf, S.M.; Al-Omran, M.; Gupta, N.; Teoh, H.; Friedrich, J.O. Colchicine in cardiac disease: A systematic review and meta-analysis of randomized controlled trials. BMC Cardiovasc. Disord. 2015, 15, 96. [CrossRef]

179. Lee, J.Z.; Singh, N.; Howe, C.L.; Low, S.-W.; Huang, J.J.; Ortega, G.; Lee, K.S.; Pandit, A. Colchicine for Prevention of PostOperative Atrial Fibrillation. JACC Clin. Electrophysiol. 2016, 2, 78-85. [CrossRef]

180. Lennerz, C.; Barman, M.; Tantawy, M.; Sopher, M.; Whittaker, P. Colchicine for primary prevention of atrial fibrillation after open-heart surgery: Systematic review and meta-analysis. Int. J. Cardiol. 2017, 249, 127-137. [CrossRef] [PubMed]

181. Barman, M.; Tantawy, M.; Sopher, M.; Lennerz, C. Cost-effectiveness of colchicine treatment on post-operative atrial fibrillation events in patients of major cardiac surgery. Eur. Heart J.-Qual. Care Clin. Outcomes 2018, 4, 126-131. [CrossRef] [PubMed]

182. Deftereos, S.; Giannopoulos, G.; Efremidis, M.; Kossyvakis, C.; Katsivas, A.; Panagopoulou, V.; Papadimitriou, C.; Karageorgiou, S.; Doudoumis, K.; Raisakis, K.; et al. Colchicine for prevention of atrial fibrillation recurrence after pulmonary vein isolation: Mid-term efficacy and effect on quality of life. Heart Rhythm 2014, 11, 620-628. [CrossRef] [PubMed]

183. Costa-Mattioli, M.; Walter, P. The integrated stress response: From mechanism to disease. Science 2020, 368, eaat5314. [CrossRef]

184. Zhang, T.; Wu, Y.; Hu, Z.; Xing, W.; Lv, K.; Wang, D.; Hu, N. Small molecule ISRIB reduces susceptibility to postinfarct atrial fibrillation in rats via inhibition of integrated stress responses. J. Pharmacol. Exp. Ther. 2021. [CrossRef] [PubMed]

185. Makary, S.; Voigt, N.; Maguy, A.; Wakili, R.; Nishida, K.; Harada, M.; Dobrev, D.; Nattel, S. Differential Protein Kinase C Isoform Regulation and Increased Constitutive Activity of Acetylcholine-Regulated Potassium Channels in Atrial Remodeling. Circ. Res. 2011, 109, 1031-1043. [CrossRef]

186. Ostropolets, A.; Elias, P.A.; Reyes, M.V.; Wan, E.Y.; Pajvani, U.B.; Hripcsak, G.; Morrow, J.P. Metformin Is Associated With a Lower Risk of Atrial Fibrillation and Ventricular Arrhythmias Compared With Sulfonylureas. Circ. Arrhythmia Electrophysiol. 2021, 14, e009115. [CrossRef] [PubMed]

187. Deshmukh, A.; Ghannam, M.; Liang, J.; Saeed, M.; Cunnane, R.; Ghanbari, H.; Latchamsetty, R.; Crawford, T.; Batul, S.A.; Chung, E.; et al. Effect of metformin on outcomes of catheter ablation for atrial fibrillation. J. Cardiovasc. Electrophysiol. 2021, 32, 1232-1239. [CrossRef]

188. Ozcan, C.; Dixit, G.; Li, Z. Activation of AMP-Activated Protein Kinases Prevents Atrial Fibrillation. J. Cardiovasc. Transl. Res. 2021, 14, 492-502. [CrossRef] [PubMed]

189. Bai, F.; Liu, Y.; Tu, T.; Li, B.; Xiao, Y.; Ma, Y.; Qin, F.; Xie, J.; Zhou, S.; Liu, Q. Metformin regulates lipid metabolism in a canine model of atrial fibrillation through AMPK/PPAR- $\alpha$ /VLCAD pathway. Lipids Health Dis. 2019, 18, 109. [CrossRef]

190. Li, J.; Li, B.; Bai, F.; Ma, Y.; Liu, N.; Liu, Y.; Wang, Y.; Liu, Q. Metformin therapy confers cardioprotection against the remodeling of gap junction in tachycardia-induced atrial fibrillation dog model. Life Sci. 2020, 254, 117759. [CrossRef]

191. Liu, L.; Gan, S.; Li, B.; Ge, X.; Yu, H.; Zhou, H. Fisetin Alleviates Atrial Inflammation, Remodeling, and Vulnerability to Atrial Fibrillation after Myocardial Infarction. Int. Heart J. 2019, 60, 1398-1406. [CrossRef] [PubMed]

192. Zhou, Z.; Li, S.; Sheng, X.; Liu, Z.; Lai, Y.; Wang, M.; Wang, Z.; Zhou, L.; Meng, G.; Chen, H.; et al. Interactions between metabolism regulator adiponectin and intrinsic cardiac autonomic nervous system: A potential treatment target for atrial fibrillation. Int. J. Cardiol. 2020, 302, 59-66. [CrossRef] [PubMed]

193. Feyz, L.; Theuns, D.A.; Bhagwandien, R.; Strachinaru, M.; Kardys, I.; Van Mieghem, N.M.; Daemen, J. Atrial fibrillation reduction by renal sympathetic denervation: 12 months' results of the AFFORD study. Clin. Res. Cardiol. 2019, 108, 634-642. [CrossRef] [PubMed]

194. Atti, V.; Turagam, M.K.; Garg, J.; Lakkireddy, D. Renal sympathetic denervation improves clinical outcomes in patients undergoing catheter ablation for atrial fibrillation and history of hypertension: A meta-analysis. J. Cardiovasc. Electrophysiol. 2019, 30, 702-708. [CrossRef]

195. Deftereos, S.; Giannopoulos, G.; Kossyvakis, C.; Efremidis, M.; Panagopoulou, V.; Raisakis, K.; Kaoukis, A.; Karageorgiou, S.; Bouras, G.; Katsivas, A.; et al. Effectiveness of Moxonidine to Reduce Atrial Fibrillation Burden in Hypertensive Patients. Am. J. Cardiol. 2013, 112, 684-687. [CrossRef] [PubMed] 
196. Giannopoulos, G.; Kossyvakis, C.; Efremidis, M.; Katsivas, A.; Panagopoulou, V.; Doudoumis, K.; Raisakis, K.; Letsas, K.; Rentoukas, I.; Pyrgakis, V.; et al. Central Sympathetic Inhibition to Reduce Postablation Atrial Fibrillation Recurrences in Hypertensive Patients. Circulation 2014, 130, 1346-1352. [CrossRef]

197. Ng, F.S.; Toman, O.; Petru, J.; Peichl, P.; Winkle, R.A.; Reddy, V.Y.; Neuzil, P.; Mead, R.H.; Qureshi, N.A.; Whinnett, Z.I.; et al. Novel Low-Voltage MultiPulse Therapy to Terminate Atrial Fibrillation. JACC Clin. Electrophysiol. 2021, 7, 988-999. [CrossRef] 